\title{
Türkiye Konjonktürel Dalgalanmalarının Temel Özellikleri
}

\author{
Bekir AŞIK *
}

\section{Öz}

Çalı̧mada 1987 - 2016yılları arasında, çeyreklik veriler kullanılarak, Türkiye konjonktürel dalgalanmalarının istatistiki özellikleri incelenmektedir. İlk olarak, konjonktürel dalgalanmalarının dönüm noktaları, Bry-Boschan algoritmasına dayalı Harding-Pagan yöntemiyle tespit edilmiştir. Daha sonra daralma/genişleme dönemlerinin ortalama süreleri, genlik ve birikimli değerleri hesaplanmıştır. Hesaplamalara göre Türkiye konjonktürel dalgalanmalarının genişleme dönemi ortalama 17 çeyrek, daralma dönemleri ise ortalama 4 çeyrek olarak tespit edilmiştir. Ayrıca, iş çevrimlerinin büyüme çevrimi tanımına uygun olarak istatistiki özellikleri de hesaplanmıştır. Seçilen makroekonomik değişkenlerin oynaklık, göreli oynaklık, GSYİH ile olan korelasyon değeri ve yapışkanlık özellikleri incelenmiştir. Seçilen makroekonomik değişkenlerin istatistiki özelliklerinin incelenebilmesi için tercih edilen Hodrick-Prescott filtreleme yönteminde, 1600 değerine ek olarak, verilerden hareketle tahmin edilen düzgünleştirme parametresi kullanılmıştır. Çalışmada Türkiye konjonktürel dalgalanmalarının istatistiki özelliklerinin gelişmekte olan ülkelerin genel özellikleriyle uyum gösterdiği tespit edilmiştir. Özellikle, Türkiye’nin GSYIH ve tüketim harcamaları oynaklı̆̆ı, net ihracatının iş çevrimleriyle ters yönlü hareket etmesi öne plana çıkmaktadır. Tüketici fiyatları endeksi ve döviz kuru değişkenlerinin yapışkanlık özellikleri de zaman içerisinde kaybolmamaktadır. Bu sonuçlara ek olarak, özel sektöre verilen kredi miktarının oynaklık değeri çıktı oynaklığının yaklaşık üç katıdır ve çıktıyla olan korelasyon değeri, bir çok gelişmekte olan ülkeden daha yüksektir.

Anahtar Sözcükler: Zaman Serisi Modelleri, Konjonktürel Dalgalanmalar, Dışa Açık Ekonomi Makroekonomisi

Jel Kodlar1 : C22, E32, F41

\section{The Basic Properties of Turkish Business Cycles}

\begin{abstract}
In this study, stylized facts of Turkish business cycles are investigated using quarterly data between 1987 and 2016. Firstly, turning points of business cycles are determined by using the Harding Pagan method based on Bry-Boschan algorithm. Then; average duration, amplitude, and cumulative movements of expansion/contraction periods are calculated. According to results, the value of average expansion periods is about 17 quarters and contraction periods is 4 quarters. In addition to these properties, other statistical properties such as volatility, relative volatility, correlation with output, and persistence are determined. The Hodrick-Prescott method is employed to examine the statistical properties of selected macroeconomic series. According to results, it is determined that the statistical properties of Turkish business cycles are in line with developing countries. In particular, high volatility of household consumption expenditures and a countercyclical pattern for net exports are the main characteristics of Turkish economy. Persistence of consumer price index and exchange rates do not decrease over time. Furthermore, the volatility of real credit is three times of the volatility of GDP and correlation with GDP is greater than most of the developing countries.
\end{abstract}

\footnotetext{
* Doktor Öğretim Üyesi, Beykent Üniversitesi, İktisadi ve İdari Bilimler Fakültesi, İktisat Bölümü, 
Key Words: Time Series Models, Business Cycles, Open Economy Macroeconomics.

JEL CODES : C22, E32, F41

\section{GİRIŞ}

İktisadi dalgalanmaların kısa ve uzun dönemli değişimlerinin nedenlerini belirlemek, konjonktürel dalgalanmalar analizinde önemli bir yer tutmaktadır. İktisadi dalgalanmaları analiz etmek için model geliştirmek, bu modelleri tahmin etmekte bu dalgalanmaların istatistiki ve çevrimsel özelliklerini belirlemek akademisyenler, politika yapıcıları ve piyasa katılımcıları açısından önemlidir. Ayrıca bu özellikleri tespit etmek, konjonktürel dalgalanmaların istatistiki özelliklerinin ve iktisat politikaların etkileşimini göz önünde bulundurarak istikrar tedbirlerinin geliştirmesine olanak sağlamaktadır.

Konjonktürel dalgalanmaların özelliklerini ve kaynaklarını tespit etmek yapısal modeller geliştirmek için gereklidir. Literatürde ülkelerin istatistiki özellikleri incelenirken konjonktürel dalgalanmalar için iki farklı tanım kullanılmaktadır. Bu tanımlardan ilki, Burns ve Mitchell (1946)'nın tanımladığı 'klasik çevrim’dir. Bu yöntemde genişleme ve daralma dönemleri iki ayrı döneme ayrılarak dalgalanmaların dönüm noktaları tespit edilir. Dalgalanmaların dönüm noktalarının tespit edilebilmesi için algoritma gereklidir ve literatürde en sık kullanılan algoritma, Bry ve Boschan (1971) algoritmasıdır. Harding ve Pagan (2002), bu algoritmayı çeyrek dönemlik verilere uyarlamıştır.

Konjonktürel dalgalanmaların istatistiki özellikleri incelenirken, literatürde kullanılan bir diğer tanım 'büyüme çevrimi'dir. Büyüme çevrimi Lucas (1977)'den hareketle Kydland ve Prescott (1990) tarafından geliştirilmiş ve reel çıktının trendden sapması olarak tanımlanmıştır. Konjonktürel dalgalanmaları bu şekilde analiz edebilmek için seriden trend arındırılmalı ve serinin çevrimsel yapısı incelenmelidir. Seçilen makroekonomik serilerin çevrimsel yapılarının trendden ayrılması ve istatistiki özeliklerinin incelenmesi için uygun trendden ayrıma yöntemi seçilmelidir.

Çalı̧mada Türkiye’nin konjonktürel dalgalanmaların hem klasik çevrim özellikleri hem de büyüme çevrim özellikleri incelenmiştir. Çalışmada öncelikle Türkiye konjonktürel dalgalanmalarının klasik çevrim özellikleri incelenmiş ve konjonktürel dalgalanmaların dönüm noktaları tespit edilmiştir. Dönüm noktaları tespit edildikten sonra konjonktürel dalgalanmaların genişleme ve daralma dönemlerinin süreleri, genlik ve genişleme (daralma) dönemlerindeki birikimli refah kazanç (kayıp) değerleri tespit edilmiştir.

Konjonktürel dalgalanmaların büyüme çevrimi özelliklerini değerlendirmek için gayri safi yurt içi hasıla, hane halkı tüketim harcamaları, yatırım harcamaları, ihracat, ithalat, net ihracatın gayri safi yurt içi hasılaya oranı, hükümet harcamaları, dış ticaret haddi, tüketici fiyatları genel seviyesi, M1, M2 ve M3 tanımlı para arzı, paranın dolaşım miktarı, reel faiz, nominal ve reel efektif döviz kuru ve özel sektöre verilen kredi değişkenleri seçilmiştir. Seçilen bu makroekonomik serilere Hodrick-Prescott, Baxter-King ve logaritmik birinci 
fark alma yöntemleri uygulanmıș ve Türkiye konjonktürel dalgalanmalarının istatistiki değerleri (oynaklık, göreli oynaklık, çıktıyla olan korelasyon değerleri ve yapışkanlık değerlerini) hesaplanmıştır.

Konjonktürel dalgalanmaların istatistiki özellikleri hesaplanırken birden fazla filtreleme yöntemi kullanılarak elde edilen sonuçlar karşılaştırılmıştır. Konjonktürel dalgalanma literatüründe seçilen veriden trendi arındırmak için en sık başvurulan yöntem HodrickPrescott (HP) filtreleme yöntemidir. HP filtreleme tekniği yaygın olarak kullanılsa da, bu yönteme eleștiriler yöneltilmekte ve her ülke için o ülkeye özgü düzgünleștirme parametresinin tahmin edilmesi gerektiği de savunulmaktadır. Çalışma kapsamında, uluslararası karşılaştırmaların yapılabilmesi için seçilen makroekonomik değişkenlere, çeyreklik veriler için düzgünleştirme parametresi 1600 olarak belirlenen HP filtreleme yöntemi uygulanmış ve sonuçlar yorumlanmıştır. Buna ek olarak, seçilen örneklem zamanında Türkiye konjonktürel dalgalanmalarının ortalama süresi göz önünde bulundurularak, Türkiye’ye özgü düzgünleştirme parametresi tahmin edilmiştir. Tahmin edilen düzgünleştirme parametresiyle HP filtreleme yöntemi kullanılarak, seçilen seriler trendden arındırılmıştır.

Türkiye'de yeni yayınlanmaya başlanan veri seti kullanılarak da konjonktürel dalgalanmalarının istatistiki özellikleri hesaplanmıștır. Türkiye İstatistik Kurumu (TÜİK), 12 Aralık 2016 tarihinde Ulusal Hesaplar Sistemi ve Avrupa Hesaplar Sistemi'ne uyum kapsamında ulusal hesaplar sistemini değiştirmiş ve yeni veri setlerini ilan etmeye başlamıştır. Türkiye’nin ulusal hesaplar sistemini değiştirmesi nedeniyle Türkiye’nin konjonktürel dalgalanmalarının istatistiki özelliklerini tespit etmek için üç farklı veri seti kullanılmıştır.

Kullanılan ilk veri seti 1987’nin birinci çeyreğiyle 2016’nın üçüncü çeyreği arasındadır. İkinci veri seti, 1998 yılının baz alınmasıyla ilan edilen veri setidir. Bu veri setinin zaman aralığı 1998 birinci çeyreğiyle 2016’nın üçüncü çeyreğidir. Çalışma kapsamında GSYİH ve bileşenlerinin iktisadi özelliklerini incelemek için kullanılan üçüncü veri seti zincirleme yöntemiyle elde edilen yeni serilerdir. Bu yeni veri seti de 1998'nin birinci çeyreğinden itibaren yayınlanmaktadır. Veri setlerinin bitiş tarihinin 2016 yılının üçüncü çeyreği olarak belirlenmesinin nedeni, eski veri setinin 2016 yılının 3. çeyreğinden itibaren yayınlanmamasıdır. GSYİH ve bileşenlerinin istatistiki özellikleri bu üç farklı veri seti kullanılarak hesaplanmıştır. Seçilen diğer makroekonomik değişkenlerin istatistiki özellikleri, 1987. Ç1 -2016. Ç3 ve 1998. Ç1 - 2016:Ç3 veri seti kullanılarak hesaplanmış ve farklı veri setlerinden elde edilen sonuçlar karşılaştırılmıştır.

Çalışmanın geri kalanı ise şu şekilde planlanmıştır: ikinci kısımda, öncelikle dönüm noktalarını tespit etmek için kullanılan yöntem tanıtılmış ve daha sonra Türkiye konjonktürel dalgalanmaların dönüm noktaları tespit edilmiştir. Dönüm noktaları tespit edildikten sonra iş çevrimlerinin daralma ve genişleme dönemlerinin süreleri ve genlik değerleri hesaplanmıştır. Üçüncü kısımda, konjonktürel dalgalanmaların istatistiki özelliklerini elde etmekte kullanılan farklı filtreleme yöntemleri tanıtılmıştır. 
Bu yöntemler tanıtıldıktan sonra farklı veri setlerinden elde edilen Türkiye konjonktürel dalgalanmaların istatistiki özellikleri hesaplanmıştır. Son olarak, dördüncü kısımda ise çalışmadan elde edilen sonuçlara yer verilmiştir.

\section{TÜRKIYYE KONJONKTÜREL DALGALANMALARININ DÖNÜM NOKTALARI}

Konjonktürel dalgalanmalar, genel olarak iktisadi aktivitelerin periyodik dalgalanmaları olarak tanimlanir. McDermott ve Scott (1999) ve Harding ve Pagan (2005)'in ifade ettiği gibi konjonktürel dalgalanmalar için iki farklı tanım bulunmaktadır. Tanımlardan ilki Burns ve Mitchell (1946)'e aittir ve 'klasik çevrim' olarak adlandırılır. Bu tanım konjonktürel dalgalanmaları, ekonomik aktivitelerde gözlemlenen genişleme ve daralma evrelerinin birbirini izlemesi olarak tanımlar. Burns ve Mitchell (1946)'in konjonktürel dalgalanma tanımı şu şekildedir: konjonktürel dalgalanma; genişleme evresinde olan birçok ekonomik aktivitenin, genişlemenin peşi sıra genel bir daralma evresine geçmesi ve daralma evresinin ardından bir sonraki çevrimin genişleme evresine geçmesidir.

Konjonktürel dalgalanmalar için geçerli olan ikinci tanım 'büyüme çevrimi' (growth cycle) olarak adlandırılır. Lucas (1977) ve Kydland ve Prescott(1990) çalışmalarından hareketle konjonktürel dalgalanma, reel çıktının trendden sapması olarak tanımlanır ve bu tanıma göre konjonktürel dalgalanmaların çevrimsel yapısının analiz edilebilmesi için söz konusu değişkenin trendden arındırılması gerekmektedir. Veriden trendin arındırılmasıyla elde edilen çevrimsel bileşene 'büyüme çevrimi' denir.

Literatürde, klasik çevrim tanımından hareketle, konjonktürel dalgalanmaların dönüm noktalarını tespit edebilmek için parametrik ve parametrik olmayan yöntemler kullanılmaktadır. Parametrik yöntemlerden ilki, genişleme ve daralma süreçlerinin simetrik olup olmadığını araştıran Neftçi (1984)'dir. Hamilton (1989) ise Markov geçişli otoregresif modeli kullanarak, bu soruya cevap aramıştır. Hamilton (1989), konjonktürel dalgalanmaları analiz ederken, gözlenemeyen rassal bir değişken tarafından etkilenen 'durum' (state) veya 'rejim' (regime) tanımlamıştır. Bu tarz modeller, Krolzig (1997) tarafından birden fazla değişkene uyarlanarak, konjonktürel dalgalanma analizinde kullanılmıştır. Konjonktürel dalgalanmaları tanımlamak için kullanılan parametrik olmayan yöntem ise (Harding ve Pagan, 2002)'ın, üç aylık verilere uyarladıkları Bry ve Boschan(1971) algoritmasıdır. Bu algoritmayla konjonktürel dalgalanmaların tepe/ dip noktaları belirlenmekte ve bu noktalar belirlendikten sonra dalgalanmaların tepe noktasıyla dip noktası arasındaki faza daralma fazı; dip noktasıyla tepe noktası arasındaki faza da genişleme fazı denmektedir. Dalgalanmaların fazları belirlendikten sonra konjonktürel dalgalanmaların fazlarının süresi ve genliği de tespit edilebilir.

\subsection{Dönüm Noktalarını Belirlemede Kullanılan Yöntem}

İlgili literatürde klasik çevrim yaklaşımına göre genişleme/daralma devrelerinin ayrımını 
gözeten dönüm noktalarını tespit etmek önemlidir. Bu dönüm noktalarını belirleme konusunda literatürde birçok yöntem bulunmaktadır (Boldin (1994) ve Massman vd. (2003)). Bu yöntemler arasında Hamilton (1989)'un lineer olmayan Markov geçişli otoregresif modeli ve non-parametrik bir yöntem olan Bry ve Boschan (1971) algoritması ön plana çıkmaktadır.

Hamilton (1989)'un Markov geçişli otoregresif modeli durgunluk ve genişleme dönemlerini asimetrik bir yapıda ele alır ve lineer olmayan bir yöntemdir. Literatürde yaygın olarak kullanılsa da, karmaşık ve parametrik lineer olmayan modellerin konjonktürel dalgalanmaların özelliklerini yakalamada lineer modellerden daha başarılı olmadığını ifade eden çalışmalar bulunmaktadır. Harding ve Pagan (2002), rassal yürüyüş özelliği olan bir modelin, ABD, Birleşik Krallık ve Avustralya konjonktürel dalgalanmalarının özelliklerini yakalayabildiğini ifade etmişlerdir. Buna ek olarak, modellere Markov geçişli otoregresif modelinde olduğu gibi lineer olmayan bir yapı eklendiğinde konjonktürel dalgalanmaların özelliklerin yakalanamadığını iddia etmişlerdir. Ayrıca Harding ve Pagan (2003), konjonktürel dalgalanmaların dönüm noktalarını belirlemede BryBoschan algoritmasının basitlik, şeffaflık, sağlamlık ve tekrar edilebilirlik gibi kriterlerle daha başarılı olduğunu belirtmiştir. Aynı şekilde Hess ve Iwata (1997), konjonktürel dalgalanmaların özelliklerini belirlemede Markov geçişli otoregresif gibi lineer olmayan yapıdaki modellerin, basit $\operatorname{ARIMA}(1,1,0)$ modelinden daha başarılı olmadığını ifade etmişlerdir.

İlgili literatürde her iki modeli karşılaştıran bir başka çalışma da Ahking (2014)'tir. Ahking (2014), Hamilton'un Markov geçişli otoregresif modelinin, kullanılan zaman aralığının ve modeldeki bir değişkenin değişmesiyle sonuçların değiştiğini ifade etmiştir. Ayrıca konjonktürel dalgalanmaların dönüm noktalarını belirlerken GSYİH ve GSMH değişkenlerini kullanınca, sonuçların da değiştiğini göstermişlerdir. Ahking (2014), BryBoschan algoritmasının konjonktürel dalgalanmaların dönüm noktalarını tespit etmede daha tutarlı sonuçlar verdiğini ifade etmişlerdir. Bu çalışmada, ilgili literatürde ifade edildiği gibi konjonktürel dalgalanmalarda daha tutarlı ve başarılı sonuçlar veren Bry ve Boschan (1971) algoritması tercih edilmiştir.

Bry ve Boschan (1971) aylık gözlemlere sahip bir seri için bu maddeleri yerine getiren bir algoritma (BB algoritmasını) geliştirmiştir. Bu algoritmada en önemli unsur zirve için $\left\{\mathrm{y}_{\mathrm{t}}>\mathrm{y}_{\mathrm{t}+\mathrm{k}}\right\}$ şartının; dip noktası için $\left\{\mathrm{y}_{\mathrm{t}}<\mathrm{y}_{\mathrm{t}-\mathrm{k}}\right\}$ şartının gerçekleştiği zaman meydana gelen zirve veya dip noktasını belirlemektir. Bu şartta $k=1,2,3, \ldots, K$ olmak üzere $K$ genelde en fazla 5 değerini alır. Bu algoritmaya göre iş çevriminin bir fazı en az 6 ayda sonlanmalı ve konjonktürel dalgalanmanın tamamı minimum 15 ay olmalıdır. (Harding, Pagan, 2002: 368).

Harding ve Pagan’ın yönteminde konjonktürel dalgalanmaların özellikleri belirlenirken, seçilen serinin dönüm noktaları tespit edilir ve daha sonra genişleme/daralma dönemleri bu noktalara göre adlandırılır. Dönüm noktalarının gözle tespit edilebilme olasılığı olsa da geliştirilen algoritma üç görevi yerine getirmelidir Harding, Pagan (2002: 368): 
seçilen serideki dönüm noktaları tespit edilmeli; dip ve tepe noktaları birbirini sırayla izler şekilde belirlenmeli; daha önceden belirenmiş konjonktürel dalgalanmanın faz büyüklügü ve süresiyle örtüşmesi amacıyla, birinci ve ikinci adımdan sonra elde edilen dönüm noktalarını birleştirmek için kurallar bütünü oluşturulmalıdır.

Harding ve Pagan, aylık verileri kullanan BB algoritmasını üç aylık verilere uyarlamışlardır ve bu algoritma, BBQ algoritması olarak adlandırılmaktadır. BBQ algoritmasında, BB algoritmasının ilk adımına benzer bir şekilde $\mathrm{K}=2$ olarak belirlenir ve şu şartları yerine getirmelidir: $\left\{\Delta_{2} \mathrm{y}_{\mathrm{t}}>0, \Delta \mathrm{y}_{\mathrm{t}}>0, \Delta \mathrm{y}_{\mathrm{t}+1}<0, \Delta_{2} \mathrm{y}_{\mathrm{t}+2}<0\right\} \Delta_{2} \mathrm{y}_{\mathrm{t}}=\mathrm{y}_{\mathrm{t}}-\mathrm{y}_{\mathrm{t}-2}^{\prime}$ dir. Bu şartla $\mathrm{y}_{\mathrm{t}}\left(\mathrm{y}_{\mathrm{t}}=\ln \right.$ $\left.\left(\mathrm{Y}_{\mathrm{t}}\right) ; \mathrm{Y}_{\mathrm{t}}=G S Y \dot{I} H\right)$ diğer iki çeyreğe göre lokal maksimum olmalıdır. $\mathrm{y}_{\mathrm{t}}$ 'nindiğer iki çeyreğe göre lokal minimum olması için $\left\{\Delta_{2} \mathrm{y}_{\mathrm{t}}<0, \Delta \mathrm{y}_{\mathrm{t}}<0, \Delta \mathrm{y}_{\mathrm{t}+1}>0, \Delta_{2} \mathrm{y}_{\mathrm{t}+2}>0\right\}$ şartlarının yerine getirilmesi gerekir.

Harding ve Pagan (2002), konjonktürel dalgalanmaların özelliklerini incelerken dalgalanmaların dört özelliğin ölçülebileceğini ifade etmişlerdir: dalgalanmanın süresi; dalgalanmanın büyüklüğü; bir fazın asimetrik davranışı ve fazdaki kümülatif hareketler.

Harding ve Pagan (2002) konjonktürel dalgalanmaların bir fazını üçgen olarak ifade edip, yukardaki kavramları bu üçgenle açılamışlardır. Harding ve Pagan (2001)'nin üçgen yaklaşımı Şekil 1'deki gibidir. Şekildeki A noktası bir daralma fazının tepe, C noktası da dip noktasını ifade etmektedir. Üçgenin yüksekliği daralma fazının genlik değerini, üçgenin tabanı ise daralma süresini vermektedir. Daralmanın süresi (üçgenin tabanı) ve daralma genliği (üçgenin yüksekliği) bilgisiyle üçgenin alanı hesaplanabilir ve konjonktürel dalgalanmanın tepe noktasından dip noktasına ulaşması durumundaki kümülatif kaybın bilgisine ulaşılabilir.

Şekil 1.Bir Daralma Fazı

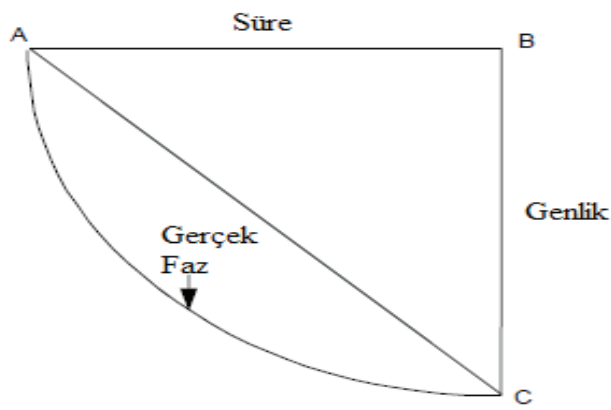


Bir konjonktürel dalgalanmanın $i$. fazının süresini $D_{i}$ ve genliğini $A_{i}$ olarak ifade edebiliriz. $C_{T i}=0.5 *\left(D_{i} * A_{i}\right)$ konjonktürel dalgalanmanın bir fazının alanını vermektedir ve bu işleme fazdaki kümülatif hareketlerinin 'üçgen yaklaşımi' adı verilmektedir. Fazın gerçek değerinin üçgen yaklaşımıyla tam olarak elde edilemediği durumda gerçekte kümülatif değer $\left(C_{i}\right), \quad C_{T i}$ 'den farklı bir değer alabilmektedir. Bu durum artık kümülatif değeriyle hesaplanabilir: $E_{i}=\left(C_{T i}-C_{i}+0.5 * A_{i}\right) / D_{i}$ (Harding, Pagan, 2001, 370).

BBQ algoritması verideki tepe ve dip noktalarını tespit eder. Bu noktalar tespit edildikten sonra seri ya daralma fazında (tepe noktası-dip noktası arası) ya da genişleme fazındadır (dip noktası-tepe noktası arası). Harding ve Pagan (2001), tepe ve dip noktalarının sayısını belirlemek için ikili değişken tanımlamıştır. Tepe noktalarının toplam sayısı, NTP = $\sum_{t=1}^{T-1}\left(1-S_{t+1}\right) S_{t}$ eşitliğiyle tespit etmektedir. t zamanında, tepe noktası için $\left(1-S_{t+1}\right) S_{t}$ bir değerini almaktadır. Bu durumda $S_{t}=1 ; S_{t+1}=0$ olmaktadır. Dip noktası için de tam tersi durum geçerlidir. Genişleme dönemlerinin toplam süresi $\sum_{t=1}^{T} S_{t}$ olduğu için genişleme döneminin ortalama süresi aşağıdaki eşitlikle tespit edilir:

$$
\widehat{D}=\frac{\sum_{t=1}^{T} S_{t}}{\sum_{t=1}^{T-1}\left(1-S_{t+1}\right) S_{t}}
$$

Harding ve Pagan (2001) genişleme ve daralma dönemlerinin ortalama genlik değerlerini aşağıdaki eşitlikle bulur.

$$
\hat{A}=\frac{\sum_{t=1}^{T} S_{t} \Delta y_{t}}{\sum_{t=1}^{T-1}\left(1-S_{t+1}\right) S_{t}}
$$

Türkiye konjonktürel dalgalanmalarının dönüm noktalarını tespit etmek için sabit fiyatlarla ölçülen üç aylık GSYİH verileri kullanılmıştır. Reel GSYİH değişkeni, Census X-12 mevsimsellikten arındırma yöntemiyle mevsimsellikten arındırılmıştır.

$Y_{t}$; Türkiye'nin üç aylık dönemindeki reel GSYIH değerini ifade eder ve $\left(y_{t}=\ln \left(Y_{t}\right)\right)$ formülüyle serinin logaritmik dönüşümü yapılmıştır². Türkiye’nin GSYİH’sının büyüme oranı, GSYİH verilerin üç aylık değerlerinin bir önceki döneme göre farkı alınarak hesaplanmıştır: $\Delta \mathrm{y}_{\mathrm{t}}=\ln \left(\mathrm{Y}_{\mathrm{t}}\right)-\ln \left(\mathrm{Y}_{\mathrm{t}-1}\right)$.

\subsection{Ortalama Daralma ve Genişleme Süreleri}

Tablo 1'de Türkiye konjonktürel dalgalanmalarının ortalama daralma ve genişleme sürelerine çeyrek dönemlik bazda yer verilmiştir. Ortalama genişleme ve daralma süreleri 1987. Ç1 - 2016. Ç3 ve 1998. Ç1 - 2016. Ç3 zaman dilimleri için hesaplanmıştır.

1987. Ç1 - 2016. Ç3 zaman dilimi için ortalama genişleme süresi 16.80 çeyrektir. Bu dönemde ortalama daralma süresi 4.20 çeyrek olmaktadır³. 1998. Ç1 - 2016. Ç3 zaman

2-Türkiye'nin 1987. Ç1 - 2016. Ç3 dönemindeki GSYİH değerleri International Financial Statistics'in internet sitesinden alınmıştır. 1998. Ç1 - 2016. Ç3 dönemindeki eski ve yeni zincirlenmiş seriler ise TÜİK’in internet sitesinden elde edilmiștir.

3-Alp vd., (2012) 1987. Ç1 - 2009. Ç4 zaman diliminde Türkiye’nin iş çevrimi istatistiklerin incelemiştir. Ortalama genişleme süresini 16.30; ortalama daralma süresini ise 4 çeyrek olarak tespit etmişlerdir. Bu çalışma 
diliminde Türkiye'nin ortalama genişleme süresi, uzun döneme kıyasla, artmış ve 17.33 çeyrek olmuştur. Kısa dönemli verilerden elde edilen ortalama daralma süresiyse, uzun dönemden elde edilen değere göre kısalmış ve 4 çeyrek olmuştur. Her iki dönemde de elde edilen değerler birbirlerine yakın çıkmaktadır.

Türkiye konjonktürel dalgalanmalarının ortalama genişleme süreleri, gelişmekte olan ülkelerin ortalama genişleme değerine yakın, yüksek orta gelirli ülkelerin ortalama genişleme süresine göre ise yüksek bir değerdir. Türkiye, ortalama daralma süresiyle, hem gelişmekte olan ülkelerin hem de yüksek orta gelirli ülkelerin ortalama genişleme değerinden düşüktür ${ }^{4}$. Türkiye, yüksek-orta gelirli gelişmekte olan ülkeler grubuna dahil bir gelişmekte olan ülke özelliğine sahiptir ve ortalama genişleme süresiyle dahil olduğu bu ülke grubundan daha yüksek bir değere, dahil olduğu ülke grubunun ortalama daralma süresinden daha az bir ortalama daralma süresine sahiptir. ${ }^{5}$

\subsection{Genlik ve Birikim}

Konjonktürel dalgalanmalarının daralma ve genişleme fazlarının genliği, söz konusu faz dönemi içerisinde ekonomik durumdaki değişimin göstergesidir. Tablo 1'de, Türkiye iş çevrimlerinin genişleme ve daralma dönemlerindeki fazların genlik değerlerine de yer verilmiştir.

Türkiye’nin 1987. Ç1 - 2016. Ç3 zaman dilimi için genişleme dönemlerindeki faz genliği 32.87'dir. Türkiye'nin 1998. Ç1 - 2016. Ç3 zaman dilimi için genişleme dönemlerindeki faz genliği ise, uzun dönemdeki genişleme dönemlerin faz genliği değerine yakın bir değer almıştır ve 33.36 olarak gerçekleşmiştir. Bu değerler gelişmekte olan ülkelerin ve yüksek orta gelirli gelişmekte olan ülke grubunun genişleme dönemlerinin faz genliğinden fazladir ${ }^{6}$.

Türkiye’nin 1987. Ç1 - 2016. Ç3 zaman dilimi için daralma dönemlerindeki faz genliği

\footnotetext{
kapsamında bulunan değerlere yakın değerlerdir.

4-Male (2010a), 32 gelişmekte olan ülkenin iş çevrimi özelliklerini incelediği çalışmasında gelişmekte olan ülkelerin ortalama genişleme süresini 16 çeyrek olarak hesaplamıştır. Yüksek gelirli gelişmekte olan ülkelerin ortalama genişleme süresi 14.8 çeyrek; yüksek-orta gelirli gelişmekte olan ülkelerin 16.6; düşük-orta gelirli gelişmekte olan ülkelerin 6 ve düşük gelirli ülkelerin ise 16 çeyrek olarak bulunmuştur. Yine bu çalışmada gelişmekte olan ülkelerin ortalama daralma süresini 5 çeyrek olarak hesaplamıştır. Yüksek gelirli gelişmekte olan ülkelerin ortalama daralma süresi 4.8 çeyrek; yüksek-orta gelirli gelişmekte olan ülkelerin 6.0; düşük-orta gelirli gelişmekte olan ülkelerin 4.9 ve düşük gelirli ülkelerin ise 5.2 çeyrek olarak bulmuştur.

5- Türkiye, Dünya Bankası̉nı 2018 yılında ülkeleri gelire dayalı olarak sıraladığı listede yüksek orta gelirli ülkeler grubunda göstermektedir. https://datahelpdesk.worldbank.org/knowledgebase/articles/906519

6-Male (2010a), gelişmekte olan ülkelerin genişleme dönemlerinde ortalama faz genliğinin 20.5 olduğunu hesaplamıştır. Yüksek gelirli gelişmekte olan ülkelerin genişleme dönemlerindeki faz genliği 11.9; yüksek-orta gelirli gelişmekte olan ülkelerin 24.7; düşük-orta gelirli gelişmekte olan ülkelerin 28.7 ve düşük gelirli ülkelerin ise 16.7 olarak bulunmuştur. Yine bu çalışmada gelişmekte olan ülkelerin daralma dönemlerinde ortalama faz genliğinin 11 olduğu hesaplanmıştır. Yüksek gelirli gelişmekte olan ülkelerin daralma dönemlerindeki faz genliği 2.7; yüksek-orta gelirli gelişmekte olan ülkelerin 13; düşük-orta gelirli gelişmekte olan ülkelerin 16.5 ve düşük gelirli ülkelerin ise 12 olarak bulunmuştur.
} 
10.71'dir. Bu değer ortalama gelişmekte olan ülkelerin daralma dönemlerinin faz genliğine yakın bir değerdir ancak Türkiye’nin üyesi olduğu yüksek orta gelirli gelişmekte olan ülkelerin daralma dönemlerinin faz değerine göre küçüktür. Türkiye’nin 1998. Ç1 - 2016. Ç3 zaman dilimi için daralma dönemlerindeki faz genliği ise uzun döneme göre artmış ve 12.49 olarak gerçekleşmiştir. Bu değer yüksek orta gelirli gelişmekte olan ülkelerin daralma dönemleri faz genişliğine yakın bir değerdir.

Tablo 1, Türkiye konjonktürel dalgalanmalarının genişleme ve daralma dönemlerindeki birikimli kazançlar ve kayıpları da göstermektedir. Konjonktürel dalgalanmanın birikimli kazancı dip noktasından tepe noktasına kadarki toplam çıktı kazancını; konjonktürel dalgalanmanın birikimli kayıbı ise tepe noktasından dip noktasında kararki toplam kaybı ifade eder. Türkiye'nin 1987. Ç1 - 2016. Ç3 zaman dilimi için genişleme dönemlerindeki birikimli kazanç yaklaşık \% 328'dir. 1998. Ç1 - 2016. Ç3 zaman dilimi için birikimli kazanç, uzun dönemdeki kazanca kıyasla artmış ve yaklaşık \% 368 olmuştur. Türkiye’nin 1987. Ç1 - 2016. Ç3 zaman dilimi için daralma dönemlerindeki birikimli kayıp yaklaşık \% 34’tür. 1998. Ç1 - 2016. Ç3 zaman dilimi için birikimli kayıp, uzun dönemdeki kazanca kıyasla artmış ve yaklaşık \% 42 olmuştur. Bu verilerden hareketle Türkiye, 1998. Ç1 - 2016. Ç3 zaman diliminde genişleme dönemlerinde elde ettiği kazanç da daralma dönemlerinde kaybettiği kayıp da 1987. Ç1 - 2016. Ç3 zaman dilimine göre artmıştır.

\section{TÜRKİYE KONJONKTÜREL DALGALANMALARININ ÖZET İSTATİSTİKI DEĞERLERI}

Konjonktürel dalgalanmaların bir başka tanımı da büyüme çevrimidir. Literatürde bu konudaki ilk çalışma, ABD verileriyle analiz yapan Kydland ve Prescott (1990)'tur. Kydland ve Prescott (1990)'un Amerika Birleşik Devletleri'ni incelediği çalışmasıyla, konjonktürel dalgalanmaların istatistiki özelliklerini araştıran çalışmaların sayısı artmıştır ${ }^{7}$. Bu makaleden sonra literatürde yapılan araştırmalar genelde gelişmiş ülkelere yöneliktir. Gelişmekte olan ülkelerin konjonktürel dalgalanmalarının özelliklerini kapsamlı bir şekilde inceleyen Agenor vd.(2000) makalesi, gelişmekte olan ülkelere yönelik öncü çalışmalardandır. Bu çalışmayı Rand ve Tarp (2002), Neumeyer ve Perri (2005), Aguiar ve Gopinath (2007), Male (2010b) ve Fernandez ve Gulan (2012) takip etmiş ve gelişmekte olan ülkelerin konjonktürel dalgalanmalarının istatistiki özelliklerine dair bilgi seti genişlemiştir.

Türkiye konjonktürel dalgalanmalarının özellikleri Alper (1998) ve Alper (2002), Berument vd.,(2005), Korap (2007) ve Alp vd., (2012) çalışmalarında incelenmiştir. Alper (1998) çalışmasında Türkiye iş çevriminin nominal stilize gerçeklerini 1978:1-1997:7 zaman aralığında, hem Hodrick-Prescott filtreleme yöntemiyle hem de 12 aylık yüzdelik değişme

7-Gelişmiş ülkelerin konjonktürel dalgalanmalarının özelliklerinin tespit edilmesi için yapılan çalışmalara örnek olarak (Backus ve Kehoe (1992), Backus vd.(1993), King ve Watson (1996), Basu ve Taylor (1999) ve Chari vd.(2002) örnek verilebilir. 
yöntemini kullanarak, araştırmıştır. Alper (2002), Türkiye ve Meksika konjonktürel dalgalanmalarını, ABD konjonktürel dalgalanmalarıyla kıyaslayarak analiz etmiştir. Berument vd., (2005) çalışmasında Türkiye konjonktürel dalgalanmalarını, Avrupa Birliği üyesi ülkeleriyle karşılaştırarak incelemişlerdir. Korap (2007), 1987. Ç1-2004. Ç4 zaman aralığında, Türkiye konjonktürel dalgalanmaları özelliklerini araştırmışlardır. Özkan ve Erden (2007) Türkiye konjonktürel dalgalanmalarının dönüm noktalarını Bry-Boschan algoritmasını kullanarak tespit etmişler ve dalgalanmaların ikiyle altı yıl aralığında olduğu sonucuna ulaşmışlardır. Alp vd., (2012), 2001 krizi öncesi ve 2001 krizi sonrasını ayrı ayrı baz alarak, Türkiye'nin konjonktürel dalgalanmaları özelliklerini analiz etmişlerdir. Alp vd., (2012), farklı zaman dilimlerinde, Türkiye konjonktürel dalgalanmalarının istatistiki özelliklerini kapsamlı bir araştırmayla ortaya koymuşlardır. Bu çalışmada istatistiki özellikler tespit edilirken Hodrick-Prescott filtreleme yöntemi kullanılmıştır. HodrickPrescott filtreleme yöntemiyle hesaplama yapılırken düzgünleştirme parametresini hem 1600 hem de Türkiye verilerini kullanarak hesapladıkları düzgünleştirme parametresi değerini (14) kullanmışlardır.

\subsection{Trendden Arındırma Yöntemi}

Rand ve Tarp (2002)'ın belirtildiği gibi iktisadi dalgalanmaları açıklayan klasik görüş belli bir zaman aralığında çıktıdaki toplam artış veya azalışı analiz eder. Bu görüşe karşılık, modern konjonktürel dalgalanma analizi ise bir zaman serisinin uzun dönemli trendinin etrafındaki çevrimsel dalgalanmalara odaklanır. Bu uzun dönemli trendin etrafındaki kısa dönemli dalgalanmalar, büyüme çevrimi olarak adlandırılır ve trendden arındırma yöntemiyle elde edilir. konjonktürel dalgalanmaları analiz ederken iktisadi seriden trendin alınması büyüme döngüsü analizini daha tutarlı yapar ve bir makroekonomik serinin ampirik özellikleri serinin durağan olması durumunda elde edilir (Rand veTarp, 2002)).

Konjonktürel dalgalanmaları incelenirken kritik nokta incelenen zaman serisinde trend bileşenini seriden ayırmaktır. Ancak uygun trendden ayırma tekniğini uygulamadan önce söz konusu zaman serisini mevsimsellikten arındırmak gerekmektedir. Seriler mevsimsellikten arındırıldıktan sonra uygun bir trendden arındırma yöntemi seçilir ve söz konusu değişkenin ikinci momentleri hesaplanır. Canova (1998) iktisadi analiz yaparken, öncü göstergelerin seçilmesi gerektiğini ve bu göstergelere ait elde edilen ikinci moment değerlerinin, makro iktisatçılar için, uygun teorik modellerin seçiminde kıstas ölçütü olabileceğini ifade etmiştir. Burnside (1998), bu görüşü desteklemekle birlikte serilerin trendden arındırılma işlemi yapılırken, kullanılan filtreleme yönteminin özelliklerine göre bilgi kaybı olacağından, sonuçların karşılaştırılabilmesi için birden fazla trendden arındırma işlemi yapılmasının gerektiğini ifade eder. Rand ve Tarp (2002)'a göre kullanılacak herhangi bir filtreleme yöntemi model sonuçlarıyla veri arasındaki farkı sağlıklı bir şekilde değerlendirebilmeyi engelleyecektir.

Çalışma kapsamında seçilen makroekonomik değişkenlerin istatistiki özelliklerini karşılaştırmak ve kullanılan filtreleme yönteminin özelliklerine göre bilgi kaybını engellemek için farklı filtreleme yöntemleri kullanılmıştır. Çalışma kapsamında seçilen 
değişkenlerden trendi arındırmak için logaritmik birinci fark alma yöntemi, Hodrick ve Prescott (1997) ve Baxter ve King (1999) yöntemi kullanılmıştır.

Hodrick ve Prescott (HP) filtresi yüksek frekanslı gürültüyü frekans bandı dışında bırakmakta ve daha kompleks yapısı nedeniyle, konjonktürel dalgalanma literatüründe, diğer filtreleme tekniklerine göre daha fazla kullanılmaktadır.

HP filtreleme tekniği seçilen serideki (), durağan olmayan trend bileşeni ile durağan olan devrevi bileşeni () birbirinden ayırmaktadır. HP filtresi, bir zaman serisindeki eğilim ve devresel hareket bileşenlerini şu formülü minimize edecek şekilde seçer ((Uribe, 2017) ve Canova, 1998)):

$$
\min _{\left\{y_{t}^{c}, y_{t}^{S}\right\}_{t=1}^{T}}\left\{\sum_{\mathrm{t}=1}^{\mathrm{T}}\left(y_{t}^{c}\right)^{2}+\lambda \sum_{\mathrm{t}=2}^{\mathrm{T}-1}\left[\left(y_{t+1}^{S}-y_{t}^{S}\right)-\left(y_{t}^{S}-y_{t-1}^{S}\right)\right]^{2}\right\}
$$

Yukarıdaki ifadede $\lambda$, düzgünleştirme parametresini ifade eder. "Bu formüle göre HP trendi, serinin çevrimsel bileşeninin varyansını minimize etmekle serinin trend bileşenin büyüme oranını sabit tutmak arasında bir değişimin sonucudur. Bu değişim $\lambda$ - düzgünleştirme parametresi tarafından yönetilir. $\lambda$ - düzgünleştirme parametresinin büyük olması durumunda trendin büyüme oranı daha fazla cezalandırılır. üzgünleştirme parametresi sonsuza giderse, HP filtresiyle ilişkili trend bileşeni lineer trendle kesişir. Diğer bir uç durum ise $\lambda$ düzgünleştirme parametresinin sıfıra gitmesidir. Bu durumda zaman serisindeki bütün değişim trenddeki değişime atfedilir ve çevrimsel bileşende değişim olmaz" (Uribe ve Schmitt-Grohe, 2017: 17).

Hodrick ve Prescott(1997) tarafından $\lambda$ düzgünleştirme parametresi, çeyreklik veriler için 1600 olarak belirlenmiştir. “ $\lambda=1600$ değerinin \% 5'lik devrevi bir hareket için uygun olduğunu ve çeyreklik olarak \% 1'lik büyümenin sekizde birine denk geldiğini ifade etmiştir. Bu nedenle düzgünleştirme parametresi için $\sqrt{ } \lambda=5 /(1 / 8)=40)$ veya $\lambda=1600$ değeri seçilmiştir” (Hodrick, Prescott, 1997: 4).

HP filtreleme tekniğinin en önemli avantajı yüksek frekanslı gürültüleri, logaritmik birinci farkın aksine, büyütmemesidir. Bu avantajına karşılık, HP filtreleme tekniğinin birkaç dezavantajı vardır ve konjonktürel dalgalanmaların istatistiki özelliklerini kullanırken dikkat etmek gerekir. HP filtreleme tekniğinin dezavantajlarından birisi serilerin filtrelenmesi sırasında yüksek frekanslı gürültüleri, konjonktürel dalgalanmaların frekans bandının dışında bırakmasıdır. Bu nedenle, HP filtreleme tekniği serinin çevrimsel bileşenini daha az değerde tahmin eder. Bir başka dezavantajı ise HP filtreleme tekniği filtrelenen seride sahte çevrimler yaratabilmektedir.

HP filtreleme tekniğine yöneltilen en önemli eleştiri, HP filtreleme tekniğinden elde edilen sonuçların $\lambda$ düzgünleştirme parametresinin seçilen değerine göre farklılıklar göstermesidir. Kydland ve Prescott (1990), çeyreklik veriler için, $\lambda$ düzgünleştirme 
parametresi değerinin 1600 olarak seçilmesinin uygun olduğunu ifade etmiştir. Hodrick ve Prescott(1997), şayet $\lambda$ değerinin 4'le çarpılıp 400 ile 6400 arasında değerler alırsa, sonuçların çok az değiştiğini ifade etmişlerdir.

Literatürde düzgünleştirme parametresi değerinin belirlenmesi konusunda bir fikir birliği bulunmamaktadır. $\lambda=1600$ olarak kullanılırsa, Canova (1998: 508)'e göre geleneksel 'band-pass' filtreleme tekniğiyle benzer sonuçlar üretmekte ve araştırmacıların ilgisini ortalama süresi 4-6 yıl olan konjonktürel dalgalanmalara yöneltmektedir. Gelişmiş ülkeler için seçilen süre uygun olarak kabul edilse de, gelişmekte olan ülkeler için iş çevrimi uzunluklarının daha kısa olduğu belirtilmektedir. Analizde kullanılacak olan düzgünleştirme parametresi değerinin, ortalama çevrim uzunluğuyla tutarlı bir değer seçilmesi gerekmektedir (Canova, 1998: 4).

Ravn ve Uhlig (2002)'e göre çeyrek dönemlik veri için $\lambda=1600$ olarak belirlemek, iş çevrimlerinin uzunluğuna bağlıdır. Rand ve Tarp (2002) ise Pedersen (2001)'den hareketle 15 gelişmekte ülkenin her biri için düzgünleştirme parametresini hesaplamışlar ve düzgünleştirme parametresinin optimal değerini 5 ila 377 arasında bulmuşlardır. Du Toit (2008), Güney Afrika için düzgünleştirme parametresi değerini 352 olarak tespit etmiştir. Alp vd. (2012) hem Pedersen (2001) hem de Dermoune vd. (2007)'nin kullandığ 1 yöntemle Türkiye için düzgünleştirme değerlerini, sırasıyla, 117 ve 14 bulmuşlardır.

Bütün eleştirilere rağmen konjonktürel dalgalanma literatüründe, özellikle ülke kıyaslamalarında, en sık kullanılan filtreleme yöntemi HP filtrelemedir. Kaiser ve Maravall (2001)'e göre HP yönteminin genelleştirilerek kullanılması filtreleme yönteminde homojenlik sağlamakta ve filtreleme tekniğinin seçiminden elde edilen sonuçlarda istikrar sağlanacağını iddia etmişlerdir.

Bu çalışma kapsamında da Türkiye konjonktürel dalgalanmalarının istatistiki özellikleri belirlenirken, uluslararası karşılaştırmaların yapılabilmesi için, seçilen veri setlerine, düzgünleştirme parametresi 1600 olarak seçilen HP filtreleme tekniği uygulanmış ve yorumlar bu yönteme göre yapılmıştır. Ancak sonuçları karşılaştırmak için, Pedersen (2001) yöntemiyle Türkiye konjonktürel dalgalanmaları için optimal düzgünleştirme parametresi de tahmin edilmiştir.

Pedersen (2001) tarafından geliştirilen yöntem çevrim uzunluklarını dikkate alarak, spektral analizi kullanan bir tahmin yapmaktadır. Bu yönteme göre veri sayısı sonlu bir değer olduğu zaman bütün filtreler, optimal filtreden sapacaktır. Bu yüzden de seçilen filtrenin bozucu etki yaratacağı düşüncesiyle geliştirilen bir yöntemdir. Bunun için bozucu etkiyi belirleyen bir ölçüt geliştirmek ve bu durumu minimize eden düzgünleştirme parametresini tahmin etmek gerekir. Pedersen (2001) yönteminin uygulanmasindan önce, konjonktürel dalgalanmalarının süre aralıklarının belirlenmesi gerekir. Bu amaçla, Bry ve Boschan (1971) tarafından geliştirilen algoritma kullanılmış, iş çevrimlerinin süre aralıkları tespit edilmiş ve Pedersen (2001) yöntemiyle düzgünleştirme parametresi 15 olarak belirlenmiştir. Bu değerle seçilen makroekonomik serilere HP filtresi uygulanmıştır. 


\subsection{HP Filtreleme Yöntemiyle Elde Edilen Sonuçların Değerlendirilmesi}

Bu bölümde farklı filtreleme teknikleri kullanarak Türkiye konjonktürel dalgalanmalarının istatistiki özellikleri elde edilmeye çalışılmıştır. Konjonktürel dalgalanmalarının istatistiki özelliklerini incelemek için GSYİH bileşenleri, net ihracat, dış ticaret hadleri, tüketici fiyatları endeksi, parasal büyüklükler, nominal ve reel efektif döviz kurları ve özel sektöre verilen kredi değişkenleri seçilmiştir. Bu değişkenler, gelişmekte olan ülkelerin konjonktürel dalgalanma özelliklerini ilk inceleyen Agenor vd. (2000) çalışması baz alınarak seçilmiştir. Verilere filtreleme tekniği uygulamadan önce veriler Census X-12 yöntemiyle mevsimsel etkilerden arındırılmıştır. Mevsimsellikten arındırılan GSYİH, hane halkı tüketim harcamaları, yatırım harcamaları, hükümet harcamaları, tüketici fiyatları genel seviyesi, parasal büyüklükler, paranın dolaşım miktarı, nominal ve reel döviz kuru, özel sektöre verilen kredi miktarının logaritması alınmıştır. Net ihracatın GSYİH değerini hesaplarken ihracat ve ithalatın farkının GSYİH’ya oranı esas alınmıştır. İstatistiki özellikler hesaplanırken reel değişkenler kullanılmıştır ${ }^{8}$. İş çevrimleri momentleri GMM (Generalised Methods of Moments) yöntemiyle elde edilmiş ve standart hatalar parantez içinde rapor edilmiştir.

\subsubsection{Oynaklık ve Göreli Oynaklık}

GSYİH ve bileşenlerinin oynaklık değerlerine Tablo 2'de, seçilen makroekonomik değişkenlerin oynaklık değerlerine Tablo 3’te yer verilmiştir. Türkiye konjonktürel dalgalanmalarının istatistiki özelliklerini incelerken göze çarpan ilk özellik GSYİH değişkeninin oynaklık değerinin yüksek oluşudur. GSYİH’nın oynaklık değeri, HP ( yöntemine göre 3.72 olarak tespit edilmiştir. Bu değer gelişmiş ülkelerin ve yükselen piyasa ekonomilerinin ortalama oynaklık değerlerinin, sırasıyla1.38 ve 2.60 , üzerindedir 9 . 1998.Ç1 - 2016.Ç3 dönemi için GSYİH oynaklığ incelendiği zaman oynaklık değeri yine yüksektir. Elde edilen sonuçları uzun dönemden elde edilen sonuçlarla kıyaslarsak, kısa dönemde elde edilen oynaklık değeri uzun dönemde elde edilen değere yakındır.

Gelişmekte olan ülkelerin tüketim harcamalarının oynaklık değeri GSYİH’nın oynaklık değerine göre yüksektir ${ }^{10}$. Türkiye de gelişmekte olan ülke kategorisinde yer aldığı için hane halkı tüketim harcamalarının oynaklık değerinin GSYIH oynaklık değerine göre fazla olması beklenir. 1987. Ç1 - 2016. Ç3 zaman aralığında her iki değişkenin oynaklık

8-Türkiye’nin 1987. Ç1 - 2016. Ç3 zaman dilimindeki veriler, reel ve nominal döviz kuru haricinde, International Financial Statistics internet sitesinden alınmıştır. Reel ve nominal döviz kuru seriler ise Federal Reserve Bank of ST. Louis (FRED)'ten alınmıştır. 1998. Ç1 - 2016. Ç3 dönemi verileriyse TÜIK'in internet sitesinden alınmıştır. 9-Bu değer Uribe ve Schmitt-Grohe(2017) çalışmasından alınmıştır. Uribe ve Schmitt-Grohe (2017)'de gelişmiş ülkeler grubunu şu ülkeler dahil edilmiştir: Amerika Birleşik Devletleri, Avustralya, Avusturya, Belçika, Birleşik Krallık, Kanada, Danimarka, Finlandiya, Fransa, Almanya, Hong Kong, İtalya, Japonya, Hollanda, Norveç, İsveç ve İsviçre. Yükselen piyasa ekonomileri grubuna ise şu ülkeler dahil edilmiştir: Arjantin, Güney Afrika, Güney Kore, İspanya, İsrail, Meksika, Peru, Portekiz, Türkiye, Uruguay ve Yeni Zelanda. Ülkelerin ortalama GSYİH oynaklık değeri 1980.Ç1-2012.Ç4 zaman aralığı için HP ( yöntemiyle elde edilmiştir.

10-Gelişmekte olan ülkelerin tüketim harcamalarının oynaklık değeri 2.60; GSYIH'nın oynaklık değeri 3.43’tür (Uribe ve Schmitt-Grohe, 2017: 29). 
değerlerini incelediğimiz zaman bu beklenti doğrulanmaktadır. HP (filtreleme yöntemiyle de aynı sonuç elde edilmiş ancak tüketim oynaklığının \% 12 daha fazla olduğu tespit edilmiştir.

Tablo 4'te GSYİH bileşenlerinin göreli oynaklık; Tablo 5’te seçilen makroekonomik değişkenlerin göreli oynaklık değerlerine yer verilmiştir. HP ( filtreleme yöntemine göre de göreli oynaklık değeri 1'den yüksek ve 1.12 değerine sahiptir. Göreli oynaklık değerinin birden büyük olması tüketim oynaklığının çıktı oynaklığından daha fazla olduğunu göstermektedir. Uribe ve Schmitt-Grohe (2017)'de tüketimin göreli oynaklık değeri gelişmiş ülkeler için 0.85; yükselen piyasa ekonomileri için 1.32 olarak bulunmuştur. Türkiye’nin göreli oynaklık değeri yükselen piyasa ekonomilerinin ortalama göreli oynaklık değerinden daha düşüktür. Bu durum, Türkiye’nin tüketim oynaklık değerinin diğer yükselen piyasa ekonomilerinin ortalama tüketim oynaklık değerinden düşük olmasından dolayı değil, gelir oynaklığının diğer ülkelerin oynaklık değerine göre aşırı yüksek olması nedeniyledir.

Türkiye’nin tüketim oynaklığının yüksek olması sürekli gelir hipoteziyle çelişmektedir. Tüketim oynaklığının fazla olmasının temel nedeni, incelenen tüketim harcamalarının dayanaklı tüketim malları harcamalarını da içermesidir. Dayanaklı tüketim malları harcamasının aşırı oynak yapısı, doğrudan tüketim harcaması olmasından ziyade hane halklarının sermayeye yatırım yapma özelliği sergilediğinden dolayı tüketimin harcamalarının istikrarlaştırılmasıyla uyumsuzdur (Uribe ve Schmitt-Grohe, 2017). Tüketim oynaklığının fazla olmasının bir başka nedeniyse finansal piyasalarının yeterince gelişmemiş olmasıdır (Özbilgin, 2009). Ayrıca Türkiye gibi gelişmekte olan ülkelerin büyük dışsal ve politika hatlarından kaynaklı içsel şoklara maruz kalması da etkilidir (Loayaza vd., 2007).

Daha istikrarlı ve kısa zaman aralığı olan 1998. Ç1 - 2016. Ç3 dönem incelendiği zaman uzun dönemli verilerden elde edilen sonuçlara göre farklılıklar gözlenmektedir. Bu zaman aralığında tüketim oynaklığıyla çıktı oynaklığının birbirine yakın değeler aldığı görülmektedir. Eski verilerden oluşan 1998. Ç1 - 2016. Ç3 dönemi için göreli tüketim oynaklı̆̆1 1.06; yeni seriye göre ise 1.00 değeri hesaplanmıştır. Her iki değer arasında çok fazla bir fark yoktur ve bu durum, tüketim oynaklığının yeni serilerde eski seriye nazaran daha düşük tespit edilmesinden kaynaklanmaktadır. Yeni seriden elde edilen göreli oynaklık değerine göre Türkiye, gelişmekte olan ülkelerin tüketim oynaklığının gelir oynaklığından fazla olma özelliğinden uzaklaştığını göstermektedir.

Literatürde gelişmekte olan ülkelerin reel GSYIH değişkenleri arasında oynaklığ 1 en fazla olan değişken yatırım harcamaları olarak bulunmaktadır. 1987. Ç1 - 2016. Ç3 zaman aralığında yatırım harcamalarının oynaklığı farklı filtreleme tekniklerinden elde edilen sonuçlara göre çıktı oynaklığının 2 ila 3 katı arasında daha fazla değerdedir ve bu sonuçlar literatürle paralellik göstermektedir. Daha istikrarlı ve kısa zaman aralığı olan 1998. Ç1 - 2016. Ç3 zincirlenmiş verilerin farklı filtreleme yöntemleriyle elde edilen oynaklık değerlerinin uzun dönemli verilerden elde edilen değerlere yakın çıktığı görülmektedir. 
İlgili literatürde gelişmiş ülkelerle ilgili bir başka ortak sonuç da hükümet harcamalarının oynaklık değerinin çıktı oynaklık değerinden fazla olmasıdır. 1987. Ç1 - 2016. Ç3 zaman aralığında hükümet harcamaların oynaklık değeri çıktı değerlerinden yaklaşık 2 kat daha fazladır. Ancak kısa zaman aralığı olan 1998. Ç1 - 2016. Ç3 dönemindeki zincirlenmiş veriler incelendiğinde hükümet harcamaları oynaklığı uzun dönemli verilerden elde edilen hükümet harcamaları oynaklığına göre daha azdır. Kısa dönemdeki hükümet harcamalarındaki oynaklık uzun döneme göre daha istikrarlı bir yapıdadır.

Hükümet harcamaları oynaklık değerleri yeni ve eski veri setine göre farklılık göstermektedir. Eski veri setine göre hükümet harcamaları oynaklığı 4.25, yeni zincirlenmiş veri setine göre ise 3.19'dur. Bu durum sadece HP (filtreleme yöntemi için değil diğer filtreleme yöntemleri için de geçerlidir. Ancak her iki veri setine göre de kısa dönemde hükümet harcamaları oynaklık değeri uzun dönemdeki oynaklık değerine göre daha azdır ve daha istikrarlı bir yapıdadır.

1987. Ç1 - 2016. Ç3 zaman aralığında dış ticaret verilerine göre hem ihracat hem de ithalat değişkenlerinin oynaklık değerleri çıktı oynaklık değerlerine kıyasla 2 ila 3 kat daha fazladır. Net ihracatın göreli oynaklık değeri ise 2.21'dir ve bu değer, gelişmekte olan ülkelerin net ihracat değişkeninin ortalama göreli oynaklık değeri olan 1.95 'ten fazladır (Uribe ve Schmitt-Grohe, 2017)). Türkiye’nin net ihracatının göreli oynaklık değeri kısa dönemde ise daha istikrarlı bir yapıdadır. 1998.Ç1-2016.Ç3 zaman aralığında net ihracatın göreli oynaklık değeri 1.90 civarındadır ve uzun döneme göre daha düşük bir oynaklık değerine sahiptir.

Diş ticaret haddi değişkenin oynaklık değeri 1987. Ç1 - 2016. Ç3 zaman aralığında 4.27 değerine sahiptir ve oynak bir yapıdadır. Buna karşın kısa dönemli veri setinde, dış ticaret haddinin oynak yapısı azalmakta ve oynaklık değeri 2.86'ya düşmektedir.

Dış ticaret değişkenleri kapsamında değerlendirilecek diğer değişkenler kurlardır. Nominal ve reel efektif döviz kurları kısa dönemde uzun döneme göre daha istikrarlı bir yapı sergilememektedir. Uzun dönemli veri setinde nominal efektif döviz kurunun oynaklık değeri 8.86 , kısa dönemli veri setinde ise 9.66; reel efektif döviz kuru oynaklık değeri ise sırasıyla 6.48 ve 6.97 olmaktadır. Her ne kadar kısa dönemde döviz kurlarının oynaklık değeri azalmamış olsa da, Türkiye’nin bu oynaklık değeri gelişmekte olan ülkelerin ortalama değerinden çok farklı değildir. Male (2010b), gelişmekte olan ülkelerin nominal efektif oynaklık değerini 9.3, reel efektif döviz kurunun ortalama oynaklık değerini ise 7.3 bulmuştur. Bu değerler Türkiyennin değerlerine yakındır.

Kurlardaki oynaklı̆̆ın azalmaması durumu fiyatlar genel seviyesi için de geçerlidir. Uzun dönemli veri setinde oynaklık değeri 4.18 , kısa dönemli veri setinde ise 4.85 'e yükselmektedir. Tüketici fiyatları genel seviyesinin göreli oynaklık değeri incelendiği zaman her iki veri setinde de çıktı oynaklığına göre daha fazladır.

M1, M2 ve M3 para arzı değişkenlerinin de oynaklık değerleri de kısa dönemde uzun 
döneme nazaran daha yüksektir. Paranın dolaşım miktarının oynaklığı ise uzun dönemde, kısa döneme kıyasla, daha fazladır. Buna ek olarak, bu değişkenlerin oynaklığı çıktı oynaklığından, her iki veri setinde, daha fazladır.

İncelenen bir diğer değişken reel faizdir. Reel faiz Merkez Bankası’nın gecelik borç verme oranıdır. Neumeyer ve Perri (2005)'ye göre reel faiz oynaklığı gelişmekte olan ülkelerde gelişmiş ülkelere göre daha fazladır. Bu durum Türkiye reel faizleri için de geçerlidir. 1990’lı yıllardaki aşırı oynak ekonomik yapı, istikrarsız politikalar ve yaşanan krizler nedeniyle, reel faiz uzun dönemli veri setinde aşırı oynaktır. Uzun zaman dilimine göre daha istikrarlı olan 1998.Ç1 - 2016. Ç3 döneminde reel faiz oynaklığı da azalmıştır.

Seçilen makroekonomik değişkenler arasında incelenecek son değişken özel sektöre verilen kredi miktarıdır. Agenor vd. (2000)'ne göre gelişmekte olan ülkelerde finansal piyasalar çok gelişmediği için özel sektör kredileri ekonomik aktivite için önem arz etmektedir. Bu nedenle Türkiye'de özel sektöre verilen kredilerin oynaklık ve göreli oynaklık değerleri de incelenmiştir. Uzun dönemli veri setinde özel sektör oynaklığı 12.90; kısa dönemli veri setinde ise oynaklık çok az azalmakta ve 11.84 olmaktadır. Özel sektöre verilen kredilerin göreli oynaklık değerleri uzun dönemde 3.47; kısa dönemde ise 3.25 olmaktadır. Bu rakamlar gelişmekte olan ülkelerin değerlerinden oldukça fazladır. Male (2010b)'e göre gelişmekte olan ülkelerde özel sektöre verilen kredilerin oynaklığ1 8.7; göreli oynaklığı ise 1.7’dir. Türkiye, özel sektöre verilen kredilerin oynaklık değeriyle, diğer gelişmekte olan ülkelerden ayrılmaktadır.

\subsubsection{GSYİH ile Korelasyon Değeri}

Seçilen $y_{t}$ gibi bir serinin, ülkelerin reel GSYIH ile birlikte hareketlerinin derecesini belirleyebilmek için korelasyon katsayısına $(\rho(\mathrm{j}), j \in\{0, \pm 1, \pm 2, \pm 3, \ldots\}$.$) ihtiyaç$ duyulmaktadır. Bu korelasyon değerleri, ve reel GSYIH serilerinin, aynı filtreleme tekniğinden elde edilen, durağan kısımlarından elde edilmiştir. Bu analizden sonra korelasyon katsayısını pozitif, sıfır veya negatif olmasına göre $y_{t}$ serisi, iş çevrimleriyle birlikte aynı yönde, iş çevrimleriyle ilgisiz ve iş çevrimleriyle ters yönde hareket ediyor şeklinde değerlendirilir.

Tablo 6'da, GSYİH bileşenlerinin GSYİH ile korelasyon değerlerine; Tablo 7'de, seçilen makroekonomik değişkenlerin GSYIH ile korelasyon değerlerine yer verilmektedir. Sonuçlara göre tüketim ve yatırım harcamaları iş çevrimleriyle aynı yönde hareket etmektedir. Korelasyon değerleri incelendiğinde, tüketim ve yatırım harcamaları ve GSYİH arasındaki korelasyon değerleri hem kısa dönemde hem de uzun dönemde pozitif ve yüksektir. Dolayısıyla, tüketim ve yatırım harcamaları konjonktür dalgalanmalarıyla aynı yönde hareket etmektedir. Tüketim ve yatırım harcamaları-GYİH arasındaki korelasyon değeri, 1998. Ç1 - 2016. Ç3 zincirlenmiş verilerde uzun döneme göre daha fazla çıkmaktadır.

Hükümet harcamaları-GSYİH arasındaki korelasyon zaman aralıklarına göre değişiklik 
göstermektedir. 1987.Ç1-2016.Ç3 zaman aralığında hükümetharcamaları-GSYİH arasında pozitif ve anlamlı bir ilişki vardır. Hükümet harcamaları da konjonktür dalgalanmalarıyla aynı yönde hareket etmektedir. Ancak 1998.Ç1-2016.Ç3 zaman dilimindeyse kullanılan filtreleme yöntemine göre sonuçlar değişiklik gösterse de genel olarak, uzun dönemdeki hükümet harcamaları ve GSYİH arasındaki güçlü ilişkinin azaldığı söylenebilir.

İhracat-GSYİH arasında, uzun dönemde, pozitif ancak istatistiki olarak anlamsız bir ilişkisi vardır. Bu durumun tek istisnası HP ( $\lambda=15$ )yöntemiyle elde edilen sonuçtur. Bu sonuca göre aradaki ilişki negatif ve istatistiki olarak anlamızdır. Zincirlenmiş verilerle ihracat-GSYİH arasındaki ilişki, farklı filtreleme yöntemleriyle incelendiği zaman korelasyon değerleri yüksek ve bu değerler istatistiki olarak anlamlıdır. İthalat-GSYİH korelasyon değerleri uzun dönemde, kullanılan tüm filtreleme yöntemlerine göre yüksek ve istatistiki olarak anlamlı değerlere sahiptir. Kısa dönemde de ithalat-GSYİH arasındaki ilişki, uzun dönemde gözlemlenen ilişkiye göre daha yüksektir.

Literatürde, gelişmekte olan ülkelerde net ihracat değişkeniyle GSYİH arasında negatif bir ilişki bulunmaktadır. Bu durum Türkiye için de hem uzun dönem de hem de kısa dönemde geçerlidir. 1987. Ç1 - 2016. Ç3 zaman aralığında net ihracatın GSYİH'ya oranıyla GSYIHH arasında negatif ancak istatistiki olarak anlamlı bir ilişki vardır. Kısa zaman aralığı olan 1998. Ç1 - 2016. Ç3 zaman aralığında da negatif ancak istatistiki olarak anlamlı bir ilişki bulunmaktadır. Yeni ve eski seri arasında farklı değerler elde edilse de aradaki negatif ve istatistiki olarak anlamlı korelasyon değeri değişmemektedir.

Dış ticaret haddi ve çıktı arasındaki ilişki gelişmiş ve gelişmekte olan ülkelerde farklı özellikler sergilemektedir. Gelişmekte olan ülkelerde dış ticaret hadleri konjonktürel dalgalanmalarla ters yönde hareket ederken, gelişmekte olan ülkelerde konjonktürel dalgalanmalarla aynı yönde hareket etmektedir (Agenor vd., 2000) ve (Rand ve Tarp, 2002). Agenor vd. (2000)'ne göre orta gelirli ülkelerin herhangi bir malın dünya fiyatlarını etkileme gücü olmadığı için dış ticaret haddi ve iş çevrimi arasında pozitif bir ilişki bulunmaktadır. Agenor vd. (2000) gelişmekte olan ülkelerdeki pozitif ilişkinin, dünya fiyatlarındaki artışla birlikte gelişmiş ülkelerin gelişmekte olan ülkelerin ihraç mallarına olan talebiyle eş anlı olarak artması nedeniyle oluşabileceğini ifade etmiştir. Türkiye’nin, 1987.Ç1-2016.Ç3 zaman aralığında, dış ticaret haddiyle çıktı arasında pozitif ancak istatistiki açıdan anlamsız bir ilişki bulunmakta ve ilişkinin işareti literatürdeki çalışmalarla paralellik göstermektedir. Kısa dönemli veri setinde ise aradaki ilişki negatif olmakta ama istatistiki olarak anlamsız olma özelliği devam etmektedir.

Döviz kurlarıla iş çevrimi arasındaki ilişkiyi incelemek için nominal ve reel döviz kuruyla çıktı arasındaki korelasyon değerleri incelenmiştir. 1987.Ç1 - 2016. Ç3 arasında her iki döviz kuruyla çıktı arasında pozitif ve istatistiki olarak anlamlı bir ilişki bulunmaktayken, bu ilişki 1998. Ç1-2016.Ç3 arasında değişmiş ve negatife dönmüştür. Her iki değişkenle çıktı arasındaki istatistiki olarak anlamlı bir ilişki olsa da, uzun dönemli veri setindeki gibi güçlü bir ilişki bulunmamaktadır. 
Tüketici fiyatları genel seviyesiyle GSYİH arasındaki ilişki incelendiği zaman diğer gelişmekte olan ülkelerde olduğu ${ }^{11}$ gibi Türkiye'de de fiyatlar ve GSYİH arasında negatif bir ilişki gözlenmektedir. Bu durum her iki veri seti için geçerlidir. Parasal değişkenlerle GSYİH arasındaki ilişkinin anlaşılabilmesi için M1, M2 ve M3 tanımlı para değişkeniyle GSYİH arasındaki ilişki incelenecektir. Ayrıca paranın dolaşım miktarıyla iş çevrimi arasındaki ilişki de analiz edilecektir. Parasal büyülklüklerle çıktı arasında pozitif ve istatistiki açıdan anlamlı bir ilişki vardır. Ancak M1 ve M3 tanımlı parasal büyüklüklerle çıktı arasında, M2 tanımlı parasal büyüklükle çıktı arasındaki ilişkiden daha güçlü bir ilişki bulunmaktadır. Paranın dolaşım miktarıyla çıktı arasında da pozitif ancak istatistiki açıdan anlamsız bir ilişki bulunmaktadır. Kısa dönemde parasal büyüklüklerle çıktı arasında, uzun dönemde olduğu gibi, pozitif ve istatistiki açıdan anlamlı bir ilişki bulunmaktadır. Paranın dolaşım miktarıyla çıktı arasındaki korelasyon değeri daha azalmış ve istatistiki açıdan anlamsızdır.

Para politikasının iş çevrimleri üzerindeki etkisini değerlendirebileceğimiz bir başka değişken de reel faizdir. İlgili literatürde gelişmekte olan ülkelerin konjonktürel dalgalanmalarıyla reel faiz arasındaki ilişkinin negatif olduğu yönünde bir fikir birliği bulunmaktadır. Çalışmamızda elde edilen sonuçlara göre hem kısa hem de uzun dönemde reel faizle iş çevrimi arasında negatif ve istatistiki olarak anlamlı bir ilişki bulunmuştur ve bu sonuçlar literatürle paralellik göstermektedir.

Agenor vd. (2000) ve Rand ve Tarp (2002)'a göre gelişmekte olan ülkelerde iş çevrimiyle özel sektöre verilen kredi arasında önemli bir ilişki bulunmaktadır. Bu sonuçlarla paralel bir sonucu Alp vd. (2012), Türkiye'nin iş çevrimlerini inceledikleri çalışmada, bulmuşlardır. Çalışmamızda da özel sektöre verilen krediyle çıktı arasında pozitif ve istatistiki açıdan anlamlı bir ilişki bulunmuştur. Bu sonuç her iki veri seti için geçerlidir.

\subsubsection{Yapıșkanlık}

Literatürde gelişmekte olan ülkelerin iş çevrimlerine ilişkin önemli bulgulardan birisi de çıktı yapışkanlığının yüksek olmasıdır. Bu çalışma kapsamında da Türkiye’nin seçilen makroekonomik değişkenlerinin yapışkanlık durumunun incelenmesi için serilerin otokorelasyon değerleri hesaplanmıştır ve sonuçlara Tablo 8'de yer verilmiştir.

GSYİH ve bileşenlerinin yapışkanlık değerleri incelendiğinde GSYİH otokorelasyonun ilk gecikme değerinin yüksek olduğu gözlenmektedir. Yapışkanlık değerleri, gecikme sayısı arttıkça, sıfıra yaklaşmaktadır. 1998. Ç1 - 2016. Ç3 dönemindeki yapışkanlık durumu, 1987. Ç1 - 2016. Ç3 dönemindeki yapışkanlık durumuyla benzerlik göstermektedir. Hane halkı tüketim harcamalarının otokorealsyon değerleri ise çıktı değişkenin otokorelasyon değerleriyle paralel sonuçlar göstermektedir. HP $(\lambda=1600)$ yöntemiyle ilk gecikme değeri yüksek ancak dördüncü gecikme de sıfıra yaklaşmaktadır. Yatırım harcamalarının otokorelasyon değerlerinin her iki dönemde de ilk gecikme değerlerinin yüksek olduğu gözlenmektedir. Bu sonuçlara ek olarak, hükümet harcamalarının otokorelasyonlarının

11-Gelişmekte olan ülkelerde fiyatlar ve GSYİH arasında negatif ilişki olduğuna dair genelleme Agenor vd (2000) ve Rand ve Tarp (2002) çalışmaları baz alınarak yapılmıştır. 
ilk gecikme değerlerinin yüksek olduğu gözlenmektedir.

Dış ticaret değişkenin GSYİH’ya oranının otokorelasyon değerlerine göre ilk otokorelasyon değerleri, çıtı değerlerinin ilk otokorelasyon değerlerine benzer bir şekilde, yüksek çıkmaktadır. Çıktı otokorelasyon değerlerinin aksine dış ticaretin GSYİH’ya oranının otokorelasyon değerleri, dördüncü gecikmede de yüksek bir değer almaktadır. Bu durum, dış ticaretin yapışkanlık özelliğinin çıktıya göre daha fazla olduğunu göstermektedir. İhracat ve ithalat değişkenleri de net ihracata benzer özellikler sergilemektedir. İhracatın kısa dönemdeki yapışkanlık değerleri ise uzun döneme göre azalmıştır. Ayrıca dış ticaret hadlerinin de otokorelasyonlarının ilk değeri diğerlerine göre yüksektir. Gecikme sayısı arttıkça yapışkanlık değerleri azalmaktadır. Kısa dönemde ise ilk iki gecikme sayısı, uzun dönemli verinin ilk iki gecikmesine göre yüksek çıkmaktadır.

Döviz kurlarının otokorelasyonlarının ilk gecikme değerleri diğer değişkenlere oranla daha azdır. Nominal efektif döviz kurunun değeri üçüncü gecikmede sıfır olmakta ancak reel efektif döviz kurunun yapışkanlık özelliği gecikme sayıları arttıkça azalmamaktadır. Reel efektif döviz kurunun yapışkanlık özelliği devamlılık göstermektedir. Yapışkanlık özelliğinin devam ettiği bir diğer değişken ise tüketici fiyatları genel seviyesidir. Tüketici fiyatları genel seviyesinin ilk gecikme değeri de yüksektir ve gecikme sayısı arttıkça yapışkanlık değeri hızla azalmamaktadır. Diğer parasal değişkenlerin yapışkanlık değerleri, tüketici fiyatları genel seviyesinin aksine daha hızlı azalmaktadır.

Gelişmekte olan ülkeler için önemli bir değişken olan özel sektöre verilen kredinin yapışkanlık değerinin ilk gecikmesi yüksek bir değerdedir. Reel efektif döviz kuru ve fiyatlar genel seviyesinde olduğu gibi gecikme sayısı arttıkça, değeri azalmamaktadır. Kısa dönemli serideki otokorelason değerleri, uzun dönemli serideki değerlere göre yüksektir. Kısa dönemli seride de ilk gecikme değeri yüksektir ve gecikme sayısı arttıkça değer azalmamaktadır.

\section{SONUÇ}

Bu çalışmada Türkiye konjonktür dalgalanmalarının karakteristik ve istatistiki özellikleri 1987.Ç1-2016.Ç3 zaman aralığında incelenmiştir. Çalışma kapsamında ilk olarak, konjonktür dalgalanmalarının dönüm noktaları tespit edilmiş, daralma ve genişleme dönemleri belirlendikten sonra daralma ve genişleme dönemlerinin ortalama süreleri ve genlik değerleri hesaplanmıştır. Ayrıca Türkiye konjonktürel dalgalanmalarının klasik çevrim tanımına göre elde edilen istatistiki özelliklerine ek olarak, büyüme çevrimi tanımına göre elde edilen istatistiki değerlerine de yer verilmiştir. Bu kapsamda GSYİH bileşenlerinin, tüketici fiyatları endeksi, döviz kurları, parasal değişkenler ve özel sektöre verilen kredi miktarının oynaklık, göreli oynaklık, yapışkanlık ve çıktıyla olan korelasyon değerleri hesaplanmıştır. 
Çalışmada Türkiye konjonktürel dalgalanmalarının 1998-2016 zaman diliminde daralma dönemlerinin süresi, 1987-2016 zaman aralığındaki daralma dönemlerinin süresine göre daha azdır. Genişleme dönemlerinin süresiyse 1998-2016 zaman diliminde daha fazladır. 1998-2016 dönemi genlik değeriyle 1987-2016 dönemindeki genlik değeri karşılaştırıldığı zaman, 1998-2016 döneminde Türkiye konjonktürel dalgalanmaları hem daralma hem de genişleme dönemlerinde daha büyük genlik değerleri tespit edilmiştir. Konjonktürel dalgalanmalarda genişleme (daralma) dönemlerinde toplam refah kazancını (toplam refah kaybını) gösteren birikim değerleri incelendiğinde 1998-2016 dönemde 19872016 döneme göre daralma fazlarındaki refah kaybında ve genişleme fazlarındaki refah kazancında bir artı̧ gözlenmektedir.

Yukarıda sıralanan özelliklere ek olarak, GSYİH'nın aşırı oynak değerlere sahip olması, tüketim harcamaları oynaklığının GSYİH oynaklığından daha fazla olması, net ihracat değişkeninin iş çevrimleriyle karşıt değerlere sahip olması Türkiye konjonktürel dalgalanmalarının belirgin özellikleri arasındadır. Türkiye konjonktürel dalgalanmalarının bu özellikleri gelişmiş ülkelerin konjonktürel dalgalanma özelliklerinden farklılıklar, gelişmekte olan ülkelerin konjonktürel dalgalanma özellikleriyle benzerlikler göstermektedir. Türkiye’nin GSYİH'nin aşırı oynak olması özelliği ise birçokgelişmekte olan ülkenin çıktı oynaklığından da fazladır. Türkiye bu özelliğiyle gelişmekte olan ülkelerden de ayrılmaktadır. Ayrıca parasal değerlerle Türkiye’nin konjonktürel dalgalanmaları üzerinde önemli bir etkisi bulunmaktadır. Türkiye konjonktürel dalgalanmaları üzerinde önemli bir etkiye sahip olan bir başka değişken de özel sektöre verilen kredi miktarıdır. Özel sektöre verilen kredi miktarının oynaklığı, çıktı oynaklığına göre yüksektir ve konjonktürel dalgalanmalarıyla pozitif yönlü bir ilişkiye sahiptir. Son olarak, 1998 sonrası dönemde makroekonomik değişkenlerin oynaklık değerlerinin, 1987-2016 arası değerlere göre azaldığı tespit edilmiştir. 


\section{KAYNAKÇA}

Ahking, F., W., (2015), “Measuring U.S. Business Cycles: A Comparison of Two Methods and Two Indicators of Economic Activities (With Appendix A)," Working papers 2015-06, University of Connecticut, Department of Economics.

Agenor, P.R., John C. McDermott, Eswar S. P., (2000),"Macroeconomic fluctuations in developing countries: some stylised facts”,World Bank Economic Review.c. 14. 251-285.

Aguiar, M., ve Gopinath G., (2007), “Emerging Market Business Cycles: The Cycle is the Trend”,Journal of Political Economy. 1-30.

Alp, H., Başkaya, Y., S., Kılınç, M., ve Yüksel, C.,(2012), “Stylized Facts for Business Cycles in Turkey”,TCMB Working Paper,No: (12/02).

Alper, C. E., (1998), “Nominal Stylized Facts for Turkish Business Cycles”,METU Studies in Development.c. 25. 233-244.

Alper, C. E., (2002),"Business Cycles, Excess Volatility and Capital Flows: Evidence from Mexico and Turkey",Russian and East European Finance and Trade.

Backus, K. D. ve Kehoe, P. J., (1992), International Evidence on the Historical Properties of Business Cycles. The American Economic Review. c. 82.s. 4. 864-888.

Backus, K. D., Kehoe, P. J., Kydland, F., E., (1993), International Business Cycle: Theory and Evidence. NBER Working Paper, No: 4493, 1-44.

Basu, S.,ve Taylor, A., M.. (1999), Business Cycles in International Historical Perspective. The Journal of Economic Perspectives. c.13.s.2. 45-68.

Baxter, M., veRobrt G. K., (1999),"Measuring Business Cycles: Approximate Band-Pass Filters for Economic Time Series”,The Review of Economics and Statistics. c.81.s. 4. 575-593.

Boldin, M., D., (1994), "Dating Turning Points in the Business Cycle”, The Journal of Business, c. 67, s. 1, 97-131.

Berument, H.,Zübeyir K. ve Yücel, E. M., (2005),"Business Cycles in Turkey and European Union Countries: A Perspective to the Membership",Sosyoekonomi,c.11. 13-26.

Bry, G. Ve Boschan, C. (1971), 'Cyclical Analysis of Time Series: Selected Procedures and Computer Programs', NBER: New York

Burns, A.F. ve Mitchell, W.C. (1946), 'Measuring Business Cycles', NBER: New York.

Burnside, Craig. (1998), “Detrending and business cycle facts: A comment”,Journal of Monetary Economics. c. 41. s.3. 513-532.

Canova, F. (1998), “Detrending and Business Cycle Facts” Journal of Monetary Economics,41; pp.475-512.

Chari, V. V., Kehoe, P.,J., McGrattan, E., R., (2002), Can Sticky Price Models Generate Volatile and Persistent Real Exchange Rates?.Review of Economic Studies.c.69. 533-563.

Dermoune, A., B. Djehiche ve N. Rahmania, (2007), “Consistent Estimators of the Smoothing Parameter in the Hodrick-Prescott Filter", Journal of Japan Statistical Society, 38(2). 
Du-Toit, L.C., (2008), “Optimal HP Filtering for South Africa”, Stellenbosch Economic Working Papers 07/08, University of Stellenbosch.

Federal Reserve Bank of St. Louis Economic Research, [25.03.2018]. https://fred.stlouisfed.org/

Fernandez,A. Ve Adam G.,(2012), "Interest Rates and Business Cycles in Emerging Economies: The Role of Financial Frictions",Inter-American Development Bank. Working Paper Series. No. 339. 1-48.

Hamilton,D. J., (1989), "A New Approach to the Economic Analysis of Nonstationary Time Series and the Business Cycle", Econometrica. c. 57.s. 2. 357-384.

Harding, D., ve Pagan, A. (2001), 'Extracting, Analysing and Using Cyclical Information' Mimeo: University Melbourne.

Harding, D., ve Pagan, A. (2002), "Dissecting the cycle: a methodological investigation” Journal of Monetary Economics,49; pp.365-381.

Harding, D., ve Pagan, A. (2003), “A Comparison of Two Business Cycle Dating Methods", Journal of Dynamics and Control, c. 27, s. 1681-1690.

Harding, D., ve Pagan, A. (2005), “A Suggested Framework for Classifying the Modes of Cycle Research”,Journal of Applied Econometrics,20; pp.151-159

Hess, G., D., ve Iwata, S., (1997), Measuring and Comparing Business Cycle Features, Journal of Business and Economic Statistics, c. 15, s. 4, 432-444.

Hodrick,J. R. ve Prescott, E. C. (1997), “Postwar U.S. Business Cycles: An Empirical Investigation”,Journal of Money, Credit, and Banking,c. 29.s.1. 1-16.

International Financial Statistics. [15.03.2018]. http://elibrary-data.imf.org/FindDataReports. aspx?d=33061\&e=169393.

Kaiser, R., ve Maravall, A., (2001), “Measuring Business Cycles in Economic Time Series”, Lecture Notes in Statistics, 154 .

King, G. R., Watson, M., W., (1996), Money, Prices, Interest Rates and the Business Cycle. The Review of Economics and Statistics.c. 78.s. 1. 35-53.

Korap, L., (2007), “Structural VAR identification of the Turkish business cycles”,Munich Personal RePEc Archive - MPRA Paper No. 21971. 1-24.

Krolzig, Hans-M., (1997), “International Business Cycles: Regime Shifts in the Stochastic Process of Economic Growth",Economics Series Working Papers. 1-31.

Kydland, E., F., ve Precott, E.C., (1990), 'Business Cycle: Real Facts and a Monetary Myth' Federal Reserve Bank of Minneapolis Quarterly Review 14 (2); 3-18

Loayaza, N., Romain R. R., Luis S. Ve Jaume V., (2007), "Macroeconomic Volatility and Welfare in Developing Countries: An Introduction”,The World Bank Economic Review. c. 21.s. 3. 343-357.

Lucas, E. R., (1977), Understanding business cycles. K. Bruner, \& A. Meltzer içinde, Stabilization of the domestic and international economy. Amsterdam: Carnigie-Rochester Conference Series on Public Policy 5. 7-29. 
Massmann, M., Mitchell, J., Weale, M., (2003), "Business Cycles and Turning Points: A Survey of Statistical Techniques, National Institute Economic Review, c. 183, c. 1, s. 90-106.

Male, R., (2010a), “Developing Country Business Cycles: Characterizing the Cycle”,School of Economics and Finance. 1-53.

Male, R., (2010b), “Developing Country Business Cycle: Revisiting the Stylised Facts”,School of Economics and Finance. (664).

McDermott, C.J., ve Scott, A. (1999), “Concordance in Business Cycles”, Reserve Bank of New Zealand Working Paper, No. G99/7.

Neftçi, N. S., (1984),“Are Economic Time Series Asymmetric over the Business Cycle?”,Journal of Political Economy.c. 92.s.2. 307-328.

Neumeyer, A. P., ve FabrizioP., (2005), “Business cycles in emerging economies: the role of interest rate”, Journal of Monetary Economics. c. 52. 345-380.

Özbilgin, H. M. (2010), “Financial Market Participation and the Developing Country Business Cycle”,Journal of Development Economics, c. 92. s.2. 125-137.

Özkan, İ. Ve Erdem, L., (2007), 'Türkiye Ekonomisinde İş Çevrimlerinin Tarih ve Süre Aralıklarının Tespiti', Akdeniz Üniversitesi İktisadi ve İdari Bilimler Fakültesi Dergisi, Cilt, 7, Sayı: 14, 1-19.

Pedersen, T.M., (2001), “The Hodrick-Prescott Filter, the Slutzky Effect, and the Distortionary Effect of Filters”, Journal of Econonomic Dynamics and Control, 25(8), 1081-1101.

Rand, J. veTarp, F. (2002), “Business Cycles in Developing Countries: Are They Different?”World Development, c. 30 . s. $12.2071-2088$.

Ravn, M. ve Uhlig, H. (2002), “On adjusting the Hodrick-Prescott filter for the frequency of observations”, The Review of Economics and Statistics, vol: 84, 2, sf: 371-375.

Uribe, M. ve Schmitt-Grohe, S. (2017), 'Open Economy Macroeconomics', Princeton University Press.

World Bank.[15.03.2018]. https://datahelpdesk.worldbank.org/knowledgebase/articles/906519-world-bankcountry-and-lending-groups 
Tablo 1. Seçilen Veri Setlerine Göre Türkiye İş Çevrimi Özelliklerinin Ortalama Değerleri

\begin{tabular}{|l|c|c|c|}
\hline & 1987.Ç1-2016.Ç3 & 1998.Ç1-2016.Ç3 & $\begin{array}{c}\text { 1998.Ç1-2016.Ç3 } \\
\text { Zincirlenmiş Veri }\end{array}$ \\
\hline Ortalama Süre (Çeyrek Dönem) & \multicolumn{3}{|l|}{} \\
\hline TD (Daralma) & 4.20 & 4.00 & 4.00 \\
\hline DT (Genişleme) & 16.80 & 17.33 & 17.33 \\
\hline Ortalama Genlik (\%) & -12.53 & -12.49 \\
\hline TD (Daralma) & -10.71 & 33.68 & 33.36 \\
\hline DT (Genişleme) & 32.87 & -40.94 & -41.51 \\
\hline Birikim (\%) & -33.60 & 371.64 & 367.49 \\
\hline TD (Daralma) & 328.90 & & \\
\hline DT (Genişleme)
\end{tabular}

Tablo 2. Türkiye’nin GSYİH ve Bileșenlerinin Oynaklık Değerleri

\begin{tabular}{|c|c|c|c|}
\hline & $\begin{array}{c}\text { 1987.Q1-2016.Q3 } \\
\text { IFS Verileri }\end{array}$ & $\begin{array}{l}\text { 1998.Q1-2016.Q3 } \\
\text { IFS Verileri }\end{array}$ & $\begin{array}{c}\text { 1998.Q1-2016.Q3 } \\
\text { Zincirlenmiş Ve- } \\
\text { riler }\end{array}$ \\
\hline \multicolumn{4}{|l|}{ Gayri Safi Yurt İçi Hasıla } \\
\hline $\begin{array}{l}\text { Hodrick-Prescott } \\
(\lambda=15)\end{array}$ & $\begin{array}{c}2.12 \\
(0.21)\end{array}$ & $\begin{array}{c}1.73 \\
(0.23)\end{array}$ & $\begin{array}{c}1.73 \\
(0.24)\end{array}$ \\
\hline $\begin{array}{l}\text { Hodrick-Prescott } \\
(\lambda=1600)\end{array}$ & $\begin{array}{c}3.72 \\
(0.35)\end{array}$ & $\begin{array}{c}3.65 \\
(0.45)\end{array}$ & $\begin{array}{c}3.62 \\
(0.45)\end{array}$ \\
\hline Baxter-King & $\begin{array}{c}3.38 \\
(0.35)\end{array}$ & $\begin{array}{c}3.61 \\
(0.46)\end{array}$ & $\begin{array}{c}3.60 \\
(0.46)\end{array}$ \\
\hline Logaritmik Birinci Fark & $\begin{array}{c}3.05 \\
(0.34)\end{array}$ & $\begin{array}{c}2.40 \\
(0.26)\end{array}$ & $\begin{array}{c}2.38 \\
(0.30)\end{array}$ \\
\hline \multicolumn{4}{|l|}{ Hane Halkı Tüketimi } \\
\hline $\begin{array}{l}\text { Hodrick-Prescott } \\
(\lambda=15)\end{array}$ & $\begin{array}{c}2.58 \\
(0.27) \\
\end{array}$ & $\begin{array}{c}1.91 \\
(0.22) \\
\end{array}$ & $\begin{array}{c}1.72 \\
(0.15) \\
\end{array}$ \\
\hline $\begin{array}{l}\text { Hodrick-Prescott } \\
(\lambda=1600)\end{array}$ & $\begin{array}{c}4.17 \\
(0.35) \\
\end{array}$ & $\begin{array}{c}3.85 \\
(0.46) \\
\end{array}$ & $\begin{array}{c}3.62 \\
(0.44) \\
\end{array}$ \\
\hline Baxter-King & $\begin{array}{c}3.56 \\
(0.38)\end{array}$ & $\begin{array}{c}3.83 \\
(0.45)\end{array}$ & $\begin{array}{c}3.73 \\
(0.42)\end{array}$ \\
\hline Logaritmik Birinci Fark & $\begin{array}{c}3.57 \\
(0.24)\end{array}$ & $\begin{array}{c}2.68 \\
(0.28) \\
\end{array}$ & $\begin{array}{c}2.52 \\
(0.24) \\
\end{array}$ \\
\hline \multicolumn{4}{|l|}{ Yatırım Harcamaları } \\
\hline $\begin{array}{l}\text { Hodrick-Prescott } \\
(\lambda=15)\end{array}$ & $\begin{array}{c}5.20 \\
(0.50)\end{array}$ & $\begin{array}{c}4.98 \\
(0.65)\end{array}$ & $\begin{array}{c}5.21 \\
(0.84)\end{array}$ \\
\hline $\begin{array}{l}\text { Hodrick-Prescott } \\
(\lambda=1600)\end{array}$ & $\begin{array}{l}10.43 \\
(0.99)\end{array}$ & $\begin{array}{l}11.04 \\
(1.30)\end{array}$ & $\begin{array}{l}11.54 \\
(1.59)\end{array}$ \\
\hline
\end{tabular}




\begin{tabular}{|l|c|c|c|}
\hline Baxter-King & $\begin{array}{c}10.29 \\
(0.99)\end{array}$ & $\begin{array}{c}11.12 \\
(1.24)\end{array}$ & $\begin{array}{c}11.86 \\
(1.50)\end{array}$ \\
\hline Logaritmik Birinci Fark & 7.00 & 6.65 & 6.57 \\
$(0.71)$ & $(0.77)$ & $(0.94)$ \\
\hline İhracat & \multicolumn{3}{|l|}{} \\
\hline Hodrick-Prescott & 5.00 & 4.56 & 3.42 \\
$(\lambda=15)$ & $(0.39)$ & $(0.42)$ & $(0.34)$ \\
\hline Hodrick-Prescott & 9.32 & 7.37 & 5.43 \\
$(\lambda=1600)$ & $(0.79)$ & $(0.66)$ & $(0.56)$ \\
\hline \multirow{2}{*}{ Baxter-King } & 8.04 & 5.80 & 3.92 \\
& $(0.80)$ & $(0.60)$ & $(0.55)$ \\
\hline Logaritmik Birinci Fark & 6.95 & 6.34 & 4.90 \\
& $(0.50)$ & $(0.54)$ & $(0.50)$ \\
\hline
\end{tabular}

Not:Serilere filtreleme yöntemleri uygulanmadan önce seriler mevsimsellikten arındırılmıştır. Mevsimsellikten arındırılan serilerin logaritması alınmış ve daha sonra farklı filtreleme yöntemleriyle serilerin çevrimsel bileşenleri elde edilmiştir. Logaritmik birinci fark yöntemi için filtreleme yöntemi uygulanmayan seriler kullanılmıştır. GMM yöntemiyle elde edilen standart hatalar parantez içerisinde belirtilmiştir. 
Tablo 2-Devam

\begin{tabular}{|l|c|c|c|}
\hline İthalat & 5.45 & 4.98 & 5.04 \\
\hline Hodrick-Prescott & $(0.44)$ & $(0.50)$ & $(0.77)$ \\
\hline$\lambda=15)$ & 10.77 & 8.92 & 9.60 \\
\hline Hodrick-Prescott & $(1.36)$ & $(1.14)$ & $(1.47)$ \\
$(\lambda=1600)$ & 10.75 & 8.48 & 9.82 \\
\hline Baxter-King & $(1.50)$ & $(1.44)$ & $(1.45)$ \\
\hline Logaritmik Birinci Fark & 7.57 & 6.65 & 6.51 \\
& $(0.71)$ & $(0.62)$ & $(0.90)$ \\
\hline Net İhracat/GSYIH & \multicolumn{3}{|l|}{} \\
\hline Hodrick-Prescott & 1.30 & 1.13 & 1.08 \\
$(\lambda=15)$ & $(0.14)$ & $(0.14)$ & $(0.11)$ \\
\hline Hodrick-Prescott & 2.21 & 1.95 & 1.88 \\
$(\lambda=1600)$ & $(0.22)$ & $(0.26)$ & $1.23)$ \\
\hline Baxter-King & 2.19 & 1.86 & $(0.23)$ \\
\hline Logaritmik Birinci Fark & $(0.23)$ & $(0.27)$ & 1.40 \\
& 1.71 & 1.46 & $(0.15)$ \\
\hline Hükümet Harcamaları & $(0.17)$ & $(0.17)$ & 2.65 \\
\hline Hodrick-Prescott & \multicolumn{3}{|c|}{} \\
$(\lambda=15)$ & 5.03 & 3.13 & $(0.25)$ \\
\hline Hodrick-Prescott & $(0.53)$ & $(0.25)$ & 3.19 \\
$(\lambda=1600)$ & 7.37 & 4.25 & $(0.27)$ \\
\hline Baxter-King & $(0.89)$ & $(0.33)$ & 2.08 \\
& 5.66 & 2.50 & $(0.20)$ \\
\hline Logaritmik Birinci Fark & $(0.92)$ & $(0.27)$ & 4.26 \\
\hline & 7.71 & 5.11 & $(0.39)$ \\
\hline
\end{tabular}

Not:Serilere filtreleme yöntemleri uygulanmadan önce seriler mevsimsellikten arındırılmıştır. Mevsimsellikten arındırılan serilerin logaritması alınmış ve daha sonra farklı filtreleme yöntemleriyle serilerin çevrimsel bileşenleri elde edilmiştir. Logaritmik birinci fark yöntemi için filtreleme yöntemi uygulanmayan seriler kullanılmıştır. GMM yöntemiyle elde edilen standart hatalar parantez içerisinde belirtilmiştir. 
Tablo 3. Seçilen Makroekonomik Değişkenlerin Oynaklık Değerleri

\begin{tabular}{|c|c|c|}
\hline & $\begin{array}{c}\text { 1987.Q1-2016.Q3 IFS } \\
\text { Verileri }\end{array}$ & $\begin{array}{c}\text { 1998.Q1-2016.Q3 } \\
\text { Zincirlenmiş Veriler }\end{array}$ \\
\hline \multicolumn{3}{|l|}{ Diş Ticaret Haddi } \\
\hline $\begin{array}{l}\text { Hodrick-Prescott } \\
(\lambda=15)\end{array}$ & $\begin{array}{c}2.45 \\
(0.29)\end{array}$ & $\begin{array}{c}1.58 \\
(0.20)\end{array}$ \\
\hline $\begin{array}{l}\text { Hodrick-Prescott } \\
(\lambda=1600)\end{array}$ & $\begin{array}{c}4.27 \\
(0.46) \\
\end{array}$ & $\begin{array}{c}2.86 \\
(0.32)\end{array}$ \\
\hline Baxter-King & $\begin{array}{c}3.18 \\
(0.40) \\
\end{array}$ & $\begin{array}{c}2.26 \\
(0.23) \\
\end{array}$ \\
\hline Logaritmik Birinci Fark & $\begin{array}{c}4.16 \\
(0.52)\end{array}$ & $\begin{array}{c}1.97 \\
(0.23)\end{array}$ \\
\hline \multicolumn{3}{|c|}{ Tüketici Fiyatları Genel Seviyesi } \\
\hline $\begin{array}{l}\text { Hodrick-Prescott } \\
(\lambda=15)\end{array}$ & $\begin{array}{c}2.01 \\
(0.36)\end{array}$ & $\begin{array}{c}1.49 \\
(0.40) \\
\end{array}$ \\
\hline $\begin{array}{l}\text { Hodrick-Prescott } \\
(\lambda=1600)\end{array}$ & $\begin{array}{c}4.18 \\
(0.65)\end{array}$ & $\begin{array}{c}4.85 \\
(0.96)\end{array}$ \\
\hline Baxter-King & $\begin{array}{c}5.69 \\
(0.88) \\
\end{array}$ & $\begin{array}{c}5.24 \\
(1.05) \\
\end{array}$ \\
\hline Logaritmik Birinci Fark & $\begin{array}{c}6.27 \\
(0.51)\end{array}$ & $\begin{array}{c}4.28 \\
(0.70)\end{array}$ \\
\hline \multicolumn{3}{|l|}{ M1 (Reel) } \\
\hline $\begin{array}{l}\text { Hodrick-Prescott } \\
(\lambda=15)\end{array}$ & $\begin{array}{c}5.95 \\
(0.82)\end{array}$ & $\begin{array}{c}5.21 \\
(1.12)\end{array}$ \\
\hline $\begin{array}{l}\text { Hodrick-Prescott } \\
(\lambda=1600)\end{array}$ & $\begin{array}{l}10.20 \\
(1.47)\end{array}$ & $\begin{array}{l}11.69 \\
(1.61)\end{array}$ \\
\hline Baxter-King & $\begin{array}{l}10.40 \\
(1.47)\end{array}$ & $\begin{array}{l}10.66 \\
(2.27)\end{array}$ \\
\hline Logaritmik Birinci Fark & $\begin{array}{c}8.69 \\
(1.39) \\
\end{array}$ & $\begin{array}{c}7.63 \\
(1.87) \\
\end{array}$ \\
\hline \multicolumn{3}{|l|}{ M2 (Reel) } \\
\hline $\begin{array}{l}\text { Hodrick-Prescott } \\
(\lambda=15)\end{array}$ & $\begin{array}{c}5.27 \\
(0.88)\end{array}$ & $\begin{array}{c}4.91 \\
(1.21)\end{array}$ \\
\hline $\begin{array}{l}\text { Hodrick-Prescott } \\
(\lambda=1600)\end{array}$ & $\begin{array}{r}9.89 \\
(1.36) \\
\end{array}$ & $\begin{array}{l}11.00 \\
(1.78)\end{array}$ \\
\hline Baxter-King & $\begin{array}{c}9.94 \\
(1.39)\end{array}$ & $\begin{array}{l}11.30 \\
(2.05)\end{array}$ \\
\hline Logaritmik Birinci Fark & $\begin{array}{c}7.47 \\
(1.53) \\
\end{array}$ & $\begin{array}{c}7.09 \\
(2.06)\end{array}$ \\
\hline \multicolumn{3}{|l|}{ M3 (Reel) } \\
\hline $\begin{array}{l}\text { Hodrick-Prescott } \\
(\lambda=15)\end{array}$ & $\begin{array}{c}5.13 \\
(0.90)\end{array}$ & $\begin{array}{c}4.93 \\
(1.28)\end{array}$ \\
\hline $\begin{array}{l}\text { Hodrick-Prescott } \\
(\lambda=1600)\end{array}$ & $\begin{array}{c}9.78 \\
(1.43)\end{array}$ & $\begin{array}{l}10.85 \\
(1.89)\end{array}$ \\
\hline
\end{tabular}




\begin{tabular}{|l|c|c|}
\hline \multirow{2}{*}{ Baxter-King } & 9.87 & 11.34 \\
& $(1.45)$ & $(2.13)$ \\
\hline \multirow{2}{*}{ Logaritmik Birinci Fark } & 7.28 & 7.16 \\
& $(1.56)$ & $(2.19)$ \\
\hline
\end{tabular}

Not:Serilere filtreleme yöntemleri uygulanmadan önce seriler mevsimsellikten arındırılmıştır. Mevsimsellikten arındırılan serilerin logaritması alınmış ve daha sonra farklı filtreleme yöntemleriyle serilerin çevrimsel bileşenleri elde edilmiştir. Logaritmik birinci fark yöntemi için filtreleme yöntemi uygulanmayan seriler kullanılmıştır. GMM yöntemiyle elde edilen standart hatalar parantez içerisinde belirtilmiştir.

Tablo 3 - Devam

\begin{tabular}{|c|c|c|}
\hline & $\begin{array}{c}\text { 1987.Q1-2016.Q3 IFS } \\
\text { Verileri }\end{array}$ & $\begin{array}{c}\text { 1998.Q1-2016.Q3 } \\
\text { Zincirlenmiș Veriler }\end{array}$ \\
\hline \multicolumn{3}{|c|}{ Para Dolaşım Miktarı (M3) } \\
\hline $\begin{array}{l}\text { Hodrick-Prescott } \\
(\lambda=15)\end{array}$ & $\begin{array}{c}7.96 \\
(1.58)\end{array}$ & $\begin{array}{c}5.35 \\
(1.05)\end{array}$ \\
\hline $\begin{array}{l}\text { Hodrick-Prescott } \\
(\lambda=1600)\end{array}$ & $\begin{array}{l}12.44 \\
(1.83)\end{array}$ & $\begin{array}{l}11.69 \\
(1.61)\end{array}$ \\
\hline Baxter-King & $\begin{array}{l}12.20 \\
(1.62)\end{array}$ & $\begin{array}{l}10.61 \\
(1.76)\end{array}$ \\
\hline Logaritmik Birinci Fark & $\begin{array}{l}11.23 \\
(2.53)\end{array}$ & $\begin{array}{c}7.81 \\
(1.61)\end{array}$ \\
\hline \multicolumn{3}{|l|}{ Reel Faiz } \\
\hline $\begin{array}{l}\text { Hodrick-Prescott } \\
(\lambda=15)\end{array}$ & $\begin{array}{l}111.11 \\
(23.83)\end{array}$ & $\begin{array}{c}0.55 \\
(0.18)\end{array}$ \\
\hline $\begin{array}{l}\text { Hodrick-Prescott } \\
(\lambda=1600)\end{array}$ & $\begin{array}{l}186.09 \\
(45.55) \\
\end{array}$ & $\begin{array}{c}0.74 \\
(0.20) \\
\end{array}$ \\
\hline Baxter-King & $\begin{array}{c}66.27 \\
(20.80)\end{array}$ & $\begin{array}{c}0.28 \\
(0.08)\end{array}$ \\
\hline Logaritmik Birinci Fark & $\begin{array}{l}159.47 \\
(36.99)\end{array}$ & $\begin{array}{c}0.85 \\
(0.26)\end{array}$ \\
\hline \multicolumn{3}{|c|}{ Nominal Efektif Döviz Kuru* } \\
\hline $\begin{array}{l}\text { Hodrick-Prescott } \\
(\lambda=15)\end{array}$ & $\begin{array}{c}5.90 \\
(1.06)\end{array}$ & $\begin{array}{c}6.34 \\
(1.17)\end{array}$ \\
\hline $\begin{array}{l}\text { Hodrick-Prescott } \\
(\lambda=1600)\end{array}$ & $\begin{array}{c}8.86 \\
(1.51)\end{array}$ & $\begin{array}{c}9.66 \\
(1.63)\end{array}$ \\
\hline Baxter-King & $\begin{array}{c}8.85 \\
(1.54)\end{array}$ & $\begin{array}{c}9.35 \\
(1.58)\end{array}$ \\
\hline Logaritmik Birinci Fark & $\begin{array}{c}3.57 \\
(0.42)\end{array}$ & $\begin{array}{l}10.33 \\
(2.02)\end{array}$ \\
\hline \multicolumn{3}{|l|}{ Reel Efektif Döviz Kuru* } \\
\hline $\begin{array}{l}\text { Hodrick-Prescott } \\
(\lambda=15)\end{array}$ & $\begin{array}{c}4.89 \\
(0.69)\end{array}$ & $\begin{array}{c}5.20 \\
(0.77)\end{array}$ \\
\hline
\end{tabular}




\begin{tabular}{|l|c|c|}
\hline $\begin{array}{l}\text { Hodrick-Prescott } \\
(\lambda=1600)\end{array}$ & $\begin{array}{c}6.48 \\
(0.93)\end{array}$ & $\begin{array}{c}6.97 \\
(1.01)\end{array}$ \\
\hline Baxter-King & 5.69 & 5.97 \\
& $(0.77)$ & $6.94)$ \\
\hline Logaritmik Birinci Fark & 7.00 & $(1.18)$ \\
\hline Özel Sektör Kredi & $(0.71)$ & 3.59 \\
\hline Hodrick-Prescott & 4.85 & $(0.47)$ \\
$(\lambda=15)$ & $(0.59)$ & 11.84 \\
\hline Hodrick-Prescott & 12.90 & $(2.10)$ \\
$(\lambda=1600)$ & $(1.70)$ & 12.82 \\
\hline Baxter-King & 13.41 & $(2.39)$ \\
\hline Logaritmik Birinci Fark & $(1.87)$ & 6.05 \\
\end{tabular}

Not:Serilere filtreleme yöntemleri uygulanmadan önce seriler mevsimsellikten arındırılmıştır. Mevsimsellikten arındırılan serilerin logaritması alınmış ve daha sonra farklı filtreleme yöntemleriyle serilerin çevrimsel bileşenleri elde edilmiştir. Logaritmik birinci fark yöntemi için filtreleme yöntemi uygulanmayan seriler kullanılmıştır. GMM yöntemiyle elde edilen standart hatalar parantez içerisinde belirtilmiştir.

${ }^{\star}$ Nominal ve reel efektif döviz kuru, veri kısıtı nedeniyle, 1994.Ç1-2016.Ç3 zaman diliminde incelenmiştir.

Tablo 4. Türkiye’nin GSYİH Bileşenlerinin Göreli Oynaklık Değerleri

\begin{tabular}{|l|c|c|c|}
\hline & $\begin{array}{c}\text { 1987.Q1-2016.Q3 } \\
\text { IFS Verileri }\end{array}$ & $\begin{array}{c}\text { 1998.Q1-2016.Q3 IFS } \\
\text { Verileri }\end{array}$ & $\begin{array}{c}\text { 1998.Q1-2016.Q3 } \\
\text { Zincirlenmiş Veriler }\end{array}$ \\
\hline Hane Halkı Tüketimi & \multicolumn{3}{|c|}{} \\
\hline Hodrick-Prescott & 1.22 & 1.11 & 1.00 \\
$(\lambda=15)$ & $(0.08)$ & $(0.09)$ & $(0.10)$ \\
\hline Hodrick-Prescott & 1.12 & 1.06 & 1.00 \\
$(\lambda=1600)$ & $(0.07)$ & $(0.05)$ & $(0.06)$ \\
\hline Baxter-King & 1.06 & 1.06 & 1.04 \\
& $(0.05)$ & $(0.04)$ & $(0.08)$ \\
\hline Logaritmik Birinci Fark & 1.17 & 1.12 & 1.06 \\
& $(0.10)$ & $(0.11)$ & $(0.11)$ \\
\hline Yatırım Harcamaları & \multicolumn{3}{|c|}{} \\
\hline Hodrick-Prescott & 2.46 & 2.88 & $(0.32)$ \\
$(\lambda=15)$ & $(0.18)$ & $(0.24)$ & 3.19 \\
\hline Hodrick-Prescott & 2.81 & 3.03 & $(0.23)$ \\
$(\lambda=1600)$ & $(0.13)$ & $(0.17)$ & \\
\hline
\end{tabular}




\begin{tabular}{|c|c|c|c|}
\hline Baxter-King & $\begin{array}{c}3.05 \\
(0.12) \\
\end{array}$ & $\begin{array}{c}3.08 \\
(0.18) \\
\end{array}$ & $\begin{array}{c}3.29 \\
(0.25) \\
\end{array}$ \\
\hline Logaritmik Birinci Fark & $\begin{array}{c}2.29 \\
(0.20) \\
\end{array}$ & $\begin{array}{c}2.77 \\
(0.21) \\
\end{array}$ & $\begin{array}{c}2.76 \\
(0.29)\end{array}$ \\
\hline \multicolumn{4}{|l|}{ İhracat } \\
\hline $\begin{array}{l}\text { Hodrick-Prescott } \\
(\lambda=15)\end{array}$ & $\begin{array}{c}2.36 \\
(0.17) \\
\end{array}$ & $\begin{array}{c}2.64 \\
(0.30) \\
\end{array}$ & $\begin{array}{c}1.98 \\
(0.26)\end{array}$ \\
\hline $\begin{array}{l}\text { Hodrick-Prescott } \\
(\lambda=1600)\end{array}$ & $\begin{array}{c}2.51 \\
(0.27)\end{array}$ & $\begin{array}{c}2.02 \\
(0.26) \\
\end{array}$ & $\begin{array}{c}1.50 \\
(0.21) \\
\end{array}$ \\
\hline Baxter-King & $\begin{array}{c}2.38 \\
(0.32) \\
\end{array}$ & $\begin{array}{c}1.61 \\
(0.25) \\
\end{array}$ & $\begin{array}{c}1.09 \\
(0.17) \\
\end{array}$ \\
\hline Logaritmik Birinci Fark & $\begin{array}{c}2.28 \\
(0.22) \\
\end{array}$ & $\begin{array}{c}2.65 \\
(0.28) \\
\end{array}$ & $\begin{array}{c}2.06 \\
(0.29) \\
\end{array}$ \\
\hline \multicolumn{4}{|l|}{ İthalat } \\
\hline $\begin{array}{l}\text { Hodrick-Prescott } \\
(\lambda=15)\end{array}$ & $\begin{array}{c}2.57 \\
(0.23) \\
\end{array}$ & $\begin{array}{c}2.89 \\
(0.31) \\
\end{array}$ & $\begin{array}{c}2.92 \\
(0.22)\end{array}$ \\
\hline $\begin{array}{l}\text { Hodrick-Prescott } \\
(\lambda=1600)\end{array}$ & $\begin{array}{c}2.90 \\
(0.38) \\
\end{array}$ & $\begin{array}{c}2.45 \\
(0.24) \\
\end{array}$ & $\begin{array}{c}2.65 \\
(0.23) \\
\end{array}$ \\
\hline Baxter-King & $\begin{array}{c}3.19 \\
(0.50)\end{array}$ & $\begin{array}{c}2.35 \\
(0.31)\end{array}$ & $\begin{array}{c}2.72 \\
(0.25)\end{array}$ \\
\hline Logaritmik Birinci Fark & $\begin{array}{c}2.48 \\
(0.24) \\
\end{array}$ & $\begin{array}{c}2.77 \\
(0.29) \\
\end{array}$ & $\begin{array}{c}2.74 \\
(0.25) \\
\end{array}$ \\
\hline \multicolumn{4}{|l|}{ Net İhracat/GSYIH } \\
\hline $\begin{array}{l}\text { Hodrick-Prescott } \\
(\lambda=15)\end{array}$ & $\begin{array}{c}0.61 \\
(0.04) \\
\end{array}$ & $\begin{array}{c}0.65 \\
(0.06) \\
\end{array}$ & $\begin{array}{c}0.62 \\
(0.07) \\
\end{array}$ \\
\hline $\begin{array}{l}\text { Hodrick-Prescott } \\
(\lambda=1600)\end{array}$ & $\begin{array}{c}0.59 \\
(0.05) \\
\end{array}$ & $\begin{array}{c}0.53 \\
(0.06) \\
\end{array}$ & $\begin{array}{c}0.52 \\
(0.06) \\
\end{array}$ \\
\hline Baxter-King & $\begin{array}{c}0.65 \\
(0.07) \\
\end{array}$ & $\begin{array}{c}0.52 \\
(0.07)\end{array}$ & $\begin{array}{c}0.52 \\
(0.07)\end{array}$ \\
\hline Logaritmik Birinci Fark & $\begin{array}{c}0.56 \\
(0.04) \\
\end{array}$ & $\begin{array}{c}0.61 \\
(0.06) \\
\end{array}$ & $\begin{array}{c}0.59 \\
(0.07) \\
\end{array}$ \\
\hline \multicolumn{4}{|l|}{ Hükümet Harcamaları } \\
\hline $\begin{array}{l}\text { Hodrick-Prescott } \\
(\lambda=15)\end{array}$ & $\begin{array}{c}2.37 \\
(0.27) \\
\end{array}$ & $\begin{array}{c}1.81 \\
(0.26) \\
\end{array}$ & $\begin{array}{c}1.53 \\
(0.26) \\
\end{array}$ \\
\hline $\begin{array}{l}\text { Hodrick-Prescott } \\
(\lambda=1600)\end{array}$ & $\begin{array}{c}1.99 \\
(0.29) \\
\end{array}$ & $\begin{array}{c}1.16 \\
(0.18) \\
\end{array}$ & $\begin{array}{c}0.88 \\
(0.13) \\
\end{array}$ \\
\hline Baxter-King & $\begin{array}{c}1.68 \\
(0.31)\end{array}$ & $\begin{array}{c}0.69 \\
(0.10)\end{array}$ & $\begin{array}{c}0.58 \\
(0.09)\end{array}$ \\
\hline Logaritmik Birinci Fark & $\begin{array}{c}2.53 \\
(0.32) \\
\end{array}$ & $\begin{array}{c}2.13 \\
(0.24) \\
\end{array}$ & $\begin{array}{c}1.79 \\
(0.28) \\
\end{array}$ \\
\hline
\end{tabular}

Not: Serilere filtreleme yöntemleri uygulanmadan önce seriler mevsimsellikten arındırılmıştır. Mevsimsellikten arındırılan serilerin logaritması alınmış ve daha sonra 
farklı filtreleme yöntemleriyle serilerin çevrimsel bileşenleri elde edilmiştir. Logaritmik birinci fark yöntemi için filtreleme yöntemi uygulanmayan seriler kullanılmıştır. GMM yöntemiyle elde edilen standart hatalar parantez içerisinde belirtilmiştir.

Tablo 5. Seçilen Makroekonomik Değişkenlerin Göreli Oynaklık Değerleri

\begin{tabular}{|c|c|c|}
\hline & $\begin{array}{c}\text { 1987.Q1-2016.Q3 IFS } \\
\text { Verileri }\end{array}$ & $\begin{array}{c}\text { 1998.Q1-2016.Q3 } \\
\text { Zincirlenmiş Veriler }\end{array}$ \\
\hline \multicolumn{3}{|l|}{ Diş Ticaret Haddi } \\
\hline $\begin{array}{l}\text { Hodrick-Prescott } \\
(\lambda=15)\end{array}$ & $\begin{array}{c}1.16 \\
(0.17)\end{array}$ & $\begin{array}{c}0.92 \\
(0.16)\end{array}$ \\
\hline $\begin{array}{l}\text { Hodrick-Prescott } \\
(\lambda=1600)\end{array}$ & $\begin{array}{c}1.15 \\
(0.16)\end{array}$ & $\begin{array}{c}0.79 \\
(0.12)\end{array}$ \\
\hline Baxter-King & $\begin{array}{c}0.94 \\
(0.15) \\
\end{array}$ & $\begin{array}{c}0.63 \\
(0.07) \\
\end{array}$ \\
\hline Logaritmik Birinci Fark & $\begin{array}{c}1.36 \\
(0.20) \\
\end{array}$ & $\begin{array}{c}0.83 \\
(0.14) \\
\end{array}$ \\
\hline \multicolumn{3}{|c|}{ Tüketici Fiyatları Genel Seviyesi } \\
\hline $\begin{array}{l}\text { Hodrick-Prescott } \\
(\lambda=15)\end{array}$ & $\begin{array}{c}0.95 \\
(0.12) \\
\end{array}$ & $\begin{array}{c}0.86 \\
(0.19) \\
\end{array}$ \\
\hline $\begin{array}{l}\text { Hodrick-Prescott } \\
(\lambda=1600)\end{array}$ & $\begin{array}{c}1.13 \\
(0.17)\end{array}$ & $\begin{array}{c}1.34 \\
(0.29)\end{array}$ \\
\hline Baxter-King & $\begin{array}{c}1.69 \\
(0.29) \\
\end{array}$ & $\begin{array}{c}1.45 \\
(0.35) \\
\end{array}$ \\
\hline Logaritmik Birinci Fark & $\begin{array}{c}2.05 \\
(0.17) \\
\end{array}$ & $\begin{array}{c}1.80 \\
(0.30)\end{array}$ \\
\hline \multicolumn{3}{|l|}{ M1 (Reel) } \\
\hline $\begin{array}{l}\text { Hodrick-Prescott } \\
(\lambda=15)\end{array}$ & $\begin{array}{c}2.81 \\
(0.45) \\
\end{array}$ & $\begin{array}{c}3.02 \\
(0.84) \\
\end{array}$ \\
\hline $\begin{array}{l}\text { Hodrick-Prescott } \\
(\lambda=1600)\end{array}$ & $\begin{array}{c}2.75 \\
(0.44) \\
\end{array}$ & $\begin{array}{c}3.23 \\
(0.63)\end{array}$ \\
\hline Baxter-King & $\begin{array}{c}3.08 \\
(0.56) \\
\end{array}$ & $\begin{array}{c}2.95 \\
(0.77) \\
\end{array}$ \\
\hline Logaritmik Birinci Fark & $\begin{array}{c}2.85 \\
(0.46) \\
\end{array}$ & $\begin{array}{c}3.21 \\
(0.91) \\
\end{array}$ \\
\hline \multicolumn{3}{|l|}{ M2 (Reel) } \\
\hline $\begin{array}{l}\text { Hodrick-Prescott } \\
(\lambda=15)\end{array}$ & $\begin{array}{c}2.49 \\
(0.46) \\
\end{array}$ & $\begin{array}{c}2.84 \\
(0.84) \\
\end{array}$ \\
\hline $\begin{array}{l}\text { Hodrick-Prescott } \\
(\lambda=1600)\end{array}$ & $\begin{array}{c}2.66 \\
(0.43) \\
\end{array}$ & $\begin{array}{c}3.04 \\
(0.65) \\
\end{array}$ \\
\hline Baxter-King & $\begin{array}{c}2.95 \\
(0.55) \\
\end{array}$ & $\begin{array}{c}3.13 \\
(0.77)\end{array}$ \\
\hline
\end{tabular}




\begin{tabular}{|l|c|c|}
\hline Logaritmik Birinci Fark & $\begin{array}{c}2.45 \\
(0.51)\end{array}$ & $\begin{array}{c}2.98 \\
(0.96)\end{array}$ \\
\hline M3 (Reel) & 2.42 & 2.86 \\
\hline Hodrick-Prescott & $(0.48)$ & $(0.89)$ \\
$(\lambda=15)$ & 2.63 & 3.00 \\
Hodrick-Prescott & $(0.44)$ & $(0.66)$ \\
$(\lambda=1600)$ & 2.92 & 3.14 \\
\hline Baxter-King & $(0.56)$ & $(0.79)$ \\
\hline Logaritmik Birinci Fark & 2.39 & 3.01 \\
& $(0.54)$ & $(1.00)$ \\
\hline Para Dolaşım Miktarı (M3) & & 3.10 \\
\hline Hodrick-Prescott & 3.76 & $(0.74)$ \\
$(\lambda=15)$ & $(0.67)$ & 3.23 \\
\hline Hodrick-Prescott & 3.35 & $(0.63)$ \\
$(\lambda=1600)$ & $(0.49)$ & 2.94 \\
\hline Baxter-King & 3.62 & $(0.69)$ \\
\hline Logaritmik Birinci Fark & $(0.60)$ & 3.28 \\
& 3.68 & $(0.78)$ \\
\hline
\end{tabular}

Not:Serilere filtreleme yöntemleri uygulanmadan önce seriler mevsimsellikten arındırılmıştır. Mevsimsellikten arındırılan serilerin logaritması alınmış ve daha sonra farklı filtreleme yöntemleriyle serilerin çevrimsel bileşenleri elde edilmiştir. Logaritmik birinci fark yöntemi için filtreleme yöntemi uygulanmayan seriler kullanılmıştır. GMM yöntemiyle elde edilen standart hatalar parantez içerisinde belirtilmiştir.

Tablo 5 - Devam

\begin{tabular}{|c|c|c|}
\hline & $\begin{array}{c}\text { 1987.Q1-2016.Q3 IFS } \\
\text { Verileri }\end{array}$ & $\begin{array}{c}\text { 1998.Q1-2016.Q3 } \\
\text { Zincirlenmiş Veriler }\end{array}$ \\
\hline \multicolumn{3}{|l|}{ Reel Faiz } \\
\hline $\begin{array}{l}\text { Hodrick-Prescott } \\
(\lambda=15)\end{array}$ & $\begin{array}{c}52.48 \\
(10.74)\end{array}$ & $\begin{array}{c}0.32 \\
(0.10)\end{array}$ \\
\hline $\begin{array}{l}\text { Hodrick-Prescott } \\
(\lambda=1600)\end{array}$ & $\begin{array}{c}50.07 \\
(13.33)\end{array}$ & $\begin{array}{c}0.20 \\
(0.06)\end{array}$ \\
\hline Baxter-King & $\begin{array}{l}19.64 \\
(6.67)\end{array}$ & $\begin{array}{c}0.08 \\
(0.02)\end{array}$ \\
\hline Logaritmik Birinci Fark & $\begin{array}{c}52.21 \\
(11.78)\end{array}$ & $\begin{array}{c}0.36 \\
(0.10)\end{array}$ \\
\hline \multicolumn{3}{|c|}{ Nominal Efektif Döviz Kuru* } \\
\hline $\begin{array}{l}\text { Hodrick-Prescott } \\
(\lambda=15)\end{array}$ & $\begin{array}{c}3.10 \\
(0.40)\end{array}$ & $\begin{array}{c}3.67 \\
(0.97)\end{array}$ \\
\hline
\end{tabular}




\begin{tabular}{|c|c|c|}
\hline $\begin{array}{l}\text { Hodrick-Prescott } \\
(\lambda=1600)\end{array}$ & $\begin{array}{c}2.36 \\
(0.39) \\
\end{array}$ & $\begin{array}{c}2.67 \\
(0.57) \\
\end{array}$ \\
\hline Baxter-King & $\begin{array}{c}2.47 \\
(0.46) \\
\end{array}$ & $\begin{array}{c}2.59 \\
(0.58) \\
\end{array}$ \\
\hline Logaritmik Birinci Fark & $\begin{array}{c}1.17 \\
(0.10)\end{array}$ & $\begin{array}{c}4.35 \\
(0.97)\end{array}$ \\
\hline \multicolumn{3}{|l|}{ Reel Efektif Döviz Kuru* } \\
\hline $\begin{array}{l}\text { Hodrick-Prescott } \\
(\lambda=15)\end{array}$ & $\begin{array}{c}2.57 \\
(0.31)\end{array}$ & $\begin{array}{c}3.01 \\
(0.71)\end{array}$ \\
\hline $\begin{array}{l}\text { Hodrick-Prescott } \\
(\lambda=1600)\end{array}$ & $\begin{array}{c}1.73 \\
(0.25) \\
\end{array}$ & $\begin{array}{c}1.92 \\
(0.40)\end{array}$ \\
\hline Baxter-King & $\begin{array}{c}1.59 \\
(0.26)\end{array}$ & $\begin{array}{c}1.66 \\
(0.39)\end{array}$ \\
\hline Logaritmik Birinci Fark & $\begin{array}{c}2.29 \\
(0.20) \\
\end{array}$ & $\begin{array}{c}2.86 \\
(0.63) \\
\end{array}$ \\
\hline \multicolumn{3}{|l|}{ Özel Sektör Kredi } \\
\hline $\begin{array}{l}\text { Hodrick-Prescott } \\
(\lambda=15)\end{array}$ & $\begin{array}{c}2.29 \\
(0.18)\end{array}$ & $\begin{array}{c}2.08 \\
(0.26)\end{array}$ \\
\hline $\begin{array}{l}\text { Hodrick-Prescott } \\
(\lambda=1600)\end{array}$ & $\begin{array}{c}3.47 \\
(0.45) \\
\end{array}$ & $\begin{array}{c}3.27 \\
(0.65) \\
\end{array}$ \\
\hline Baxter-King & $\begin{array}{c}3.97 \\
(0.62)\end{array}$ & $\begin{array}{c}3.55 \\
(0.84)\end{array}$ \\
\hline Logaritmik Birinci Fark & $\begin{array}{c}2.38 \\
(0.20)\end{array}$ & $\begin{array}{c}2.54 \\
(0.38) \\
\end{array}$ \\
\hline
\end{tabular}

Not:Serilere filtreleme yöntemleri uygulanmadan önce seriler mevsimsellikten arındırılmıştır. Mevsimsellikten arındırılan serilerin logaritması alınmış ve daha sonra farklı filtreleme yöntemleriyle serilerin çevrimsel bileşenleri elde edilmiştir. Logaritmik birinci fark yöntemi için filtreleme yöntemi uygulanmayan seriler kullanılmıştır. GMM yöntemiyle elde edilen standart hatalar parantez içerisinde belirtilmiştir.

*Nominal ve reel efektif döviz kuru, veri kısıtı nedeniyle, 1994.Ç1-2016.Ç3 zaman diliminde incelenmiştir. 
Tablo 6.Türkiye’nin GSYIH Bileşenlerinin GSYIHH Korelasyon Değerleri

\begin{tabular}{|c|c|c|c|}
\hline & $\begin{array}{c}\text { 1987.Q1-2016.Q3 IFS } \\
\text { Verileri }\end{array}$ & $\begin{array}{c}\text { 1998.Q1-2016.Q3 IFS } \\
\text { Verileri }\end{array}$ & $\begin{array}{c}\text { 1998.Q1-2016.Q3 } \\
\text { Zincirlenmiș Veriler }\end{array}$ \\
\hline \multicolumn{4}{|l|}{ Hane Halkı Tüketimi } \\
\hline $\begin{array}{l}\text { Hodrick-Prescott } \\
(\lambda=15)\end{array}$ & $\begin{array}{c}0.72 \\
(0.07)\end{array}$ & $\begin{array}{c}0.75 \\
(0.07)\end{array}$ & $\begin{array}{c}0.74 \\
(0.06)\end{array}$ \\
\hline $\begin{array}{l}\text { Hodrick-Prescott } \\
(\lambda=1600)\end{array}$ & $\begin{array}{c}0.82 \\
(0.05) \\
\end{array}$ & $\begin{array}{c}0.90 \\
(0.03) \\
\end{array}$ & $\begin{array}{c}0.88 \\
(0.04) \\
\end{array}$ \\
\hline Baxter-King & $\begin{array}{c}0.89 \\
(0.04)\end{array}$ & $\begin{array}{c}0.95 \\
(0.02)\end{array}$ & $\begin{array}{c}0.92 \\
(0.03)\end{array}$ \\
\hline Logaritmik Birinci Fark & $\begin{array}{c}0.65 \\
(0.09)\end{array}$ & $\begin{array}{c}0.69 \\
(0.09) \\
\end{array}$ & $\begin{array}{c}0.68 \\
(0.07) \\
\end{array}$ \\
\hline \multicolumn{4}{|l|}{ Yatırım Harcamaları } \\
\hline $\begin{array}{l}\text { Hodrick-Prescott } \\
(\lambda=15)\end{array}$ & $\begin{array}{c}0.74 \\
(0.06)\end{array}$ & $\begin{array}{c}0.87 \\
(0.04) \\
\end{array}$ & $\begin{array}{c}0.83 \\
(0.05)\end{array}$ \\
\hline $\begin{array}{l}\text { Hodrick-Prescott } \\
(\lambda=1600)\end{array}$ & $\begin{array}{c}0.85 \\
(0.05)\end{array}$ & $\begin{array}{c}0.95 \\
(0.02)\end{array}$ & $\begin{array}{c}0.94 \\
(0.02)\end{array}$ \\
\hline Baxter-King & $\begin{array}{c}0.91 \\
(0.03)\end{array}$ & $\begin{array}{c}0.96 \\
(0.02) \\
\end{array}$ & $\begin{array}{c}0.96 \\
(0.01) \\
\end{array}$ \\
\hline Logaritmik Birinci Fark & $\begin{array}{c}0.75 \\
(0.06)\end{array}$ & $\begin{array}{c}0.85 \\
(0.04)\end{array}$ & $\begin{array}{c}0.80 \\
(0.05)\end{array}$ \\
\hline \multicolumn{4}{|l|}{ İhracat } \\
\hline $\begin{array}{l}\text { Hodrick-Prescott } \\
(\lambda=15)\end{array}$ & $\begin{array}{l}-0.05 \\
(0.17) \\
\end{array}$ & $\begin{array}{c}0.14 \\
(0.21) \\
\end{array}$ & $\begin{array}{c}0.53 \\
(0.11) \\
\end{array}$ \\
\hline $\begin{array}{l}\text { Hodrick-Prescott } \\
(\lambda=1600)\end{array}$ & $\begin{array}{c}0.05 \\
(0.17)\end{array}$ & $\begin{array}{c}0.26 \\
(0.21)\end{array}$ & $\begin{array}{c}0.66 \\
(0.07)\end{array}$ \\
\hline Baxter-King & $\begin{array}{c}0.02 \\
(0.22)\end{array}$ & $\begin{array}{c}0.20 \\
(0.25) \\
\end{array}$ & $\begin{array}{c}0.73 \\
(0.10) \\
\end{array}$ \\
\hline Logaritmik Birinci Fark & $\begin{array}{c}0.08 \\
(0.16)\end{array}$ & $\begin{array}{c}0.27 \\
(0.19)\end{array}$ & $\begin{array}{c}0.50 \\
(0.11) \\
\end{array}$ \\
\hline \multicolumn{4}{|l|}{ İthalat } \\
\hline $\begin{array}{l}\text { Hodrick-Prescott } \\
(\lambda=15)\end{array}$ & $\begin{array}{c}0.45 \\
(0.12)\end{array}$ & $\begin{array}{c}0.60 \\
(0.09)\end{array}$ & $\begin{array}{c}0.78 \\
(0.07) \\
\end{array}$ \\
\hline $\begin{array}{l}\text { Hodrick-Prescott } \\
(\lambda=1600)\end{array}$ & $\begin{array}{c}0.55 \\
(0.10) \\
\end{array}$ & $\begin{array}{c}0.74 \\
(0.07) \\
\end{array}$ & $\begin{array}{c}0.86 \\
(0.04) \\
\end{array}$ \\
\hline Baxter-King & $\begin{array}{c}0.63 \\
(0.10)\end{array}$ & $\begin{array}{c}0.85 \\
(0.05)\end{array}$ & $\begin{array}{c}0.90 \\
(0.04)\end{array}$ \\
\hline Logaritmik Birinci Fark & $\begin{array}{c}0.34 \\
(0.16)\end{array}$ & $\begin{array}{c}0.60 \\
(0.08) \\
\end{array}$ & $\begin{array}{c}0.72 \\
(0.08) \\
\end{array}$ \\
\hline \multicolumn{4}{|l|}{ Net İhracat/GSYIH } \\
\hline $\begin{array}{l}\text { Hodrick-Prescott } \\
(\lambda=15)\end{array}$ & $\begin{array}{l}-0.42 \\
(0.15)\end{array}$ & $\begin{array}{l}-0.52 \\
(0.12)\end{array}$ & $\begin{array}{l}-0.42 \\
(0.14)\end{array}$ \\
\hline
\end{tabular}




\begin{tabular}{|l|c|c|c|}
\hline Hodrick-Prescott & -0.54 & -0.64 & -0.55 \\
$(\lambda=1600)$ & $(0.12)$ & $(0.11)$ & $(0.13)$ \\
\hline \multirow{2}{*}{ Baxter-King } & -0.68 & -0.82 & -0.73 \\
& $(0.11)$ & $(0.08)$ & $(0.11)$ \\
\hline \multirow{2}{*}{ Logaritmik Birinci Fark } & -0.22 & -0.39 & -0.35 \\
& $(0.19)$ & $(0.15)$ & $(0.15)$ \\
\hline
\end{tabular}

\begin{tabular}{|l|c|c|c|}
\hline Hükümet Harcamaları & \multicolumn{3}{|c|}{} \\
\hline Hodrick-Prescott & 0.37 & 0.13 & 0.27 \\
$(\lambda=15)$ & $(0.11)$ & $(0.12)$ & $(0.10)$ \\
\hline Hodrick-Prescott & 0.38 & 0.08 & 0.12 \\
$(\lambda=1600)$ & $(0.10)$ & $(0.15)$ & $(0.14)$ \\
\hline \multirow{2}{*}{ Baxter-King } & 0.39 & 0.26 & 0.07 \\
& $(0.13)$ & $(0.25)$ & $(0.25)$ \\
\hline \multirow{2}{*}{ Logaritmik Birinci Fark } & 0.34 & 0.16 & 0.26 \\
& $(0.13)$ & $(0.15)$ & $(0.10)$ \\
\hline
\end{tabular}

Not:Serilere filtreleme yöntemleri uygulanmadan önce seriler mevsimsellikten arındırılmıştır. Mevsimsellikten arındırılan serilerin logaritması alınmış ve daha sonra farklı filtreleme yöntemleriyle serilerin çevrimsel bileşenleri elde edilmiştir. Logaritmik birinci fark yöntemi için filtreleme yöntemi uygulanmayan seriler kullanılmıştır. GMM yöntemiyle elde edilen standart hatalar parantez içerisinde belirtilmiştir.

Tablo 7.Seçilen Makroekonomik Değişkenlerin GSYIH Korelasyon Değerleri

\begin{tabular}{|l|c|c|}
\hline \multicolumn{2}{|c|}{ 1987.Q1-2016.Q3 IFS Verileri } & $\begin{array}{c}\text { 1998.Q1-2016.Q3 } \\
\text { Zincirlenmiş Veriler }\end{array}$ \\
\hline Diş Ticaret Haddi & 0.20 \\
\hline $\begin{array}{l}\text { Hodrick-Prescott } \\
\lambda=15)\end{array}$ & $(0.10)$ & -0.003 \\
\hline Hodrick-Prescott & 0.18 & $(0.09)$ \\
$(\lambda=1600)$ & $(0.11)$ & -0.18 \\
Baxter-King & 0.07 & $(0.14)$ \\
\hline Logaritmik Birinci Fark & $(0.16)$ & -0.17 \\
\hline Tüketici Fiyatları Genel Seviyesi & 0.21 & $(0.24)$ \\
\hline Hodrick-Prescott & $(0.08)$ & 0.02 \\
$(\lambda=15)$ & & $(0.08)$ \\
\hline Hodrick-Prescott & -0.38 & -0.33 \\
$(\lambda=1600)$ & $(0.15)$ & $(0.11)$ \\
\hline Baxter-King & -0.44 & -0.51 \\
& $(0.12)$ & $(0.13)$ \\
\hline
\end{tabular}




\begin{tabular}{|c|c|c|}
\hline Logaritmik Birinci Fark & $\begin{array}{l}-0.20 \\
(0.14) \\
\end{array}$ & $\begin{array}{l}-0.33 \\
(0.15)\end{array}$ \\
\hline \multicolumn{3}{|l|}{ M1 (Reel) } \\
\hline $\begin{array}{l}\text { Hodrick-Prescott } \\
(\lambda=15)\end{array}$ & $\begin{array}{c}0.21 \\
(0.15)\end{array}$ & $\begin{array}{c}0.29 \\
(0.10)\end{array}$ \\
\hline $\begin{array}{l}\text { Hodrick-Prescott } \\
(\lambda=1600)\end{array}$ & $\begin{array}{c}0.43 \\
(0.11) \\
\end{array}$ & $\begin{array}{c}0.48 \\
(0.17)\end{array}$ \\
\hline Baxter-King & $\begin{array}{c}0.47 \\
(0.11)\end{array}$ & $\begin{array}{c}0.49 \\
(0.11)\end{array}$ \\
\hline Logaritmik Birinci Fark & $\begin{array}{c}0.15 \\
(0.18) \\
\end{array}$ & $\begin{array}{c}0.29 \\
(0.07) \\
\end{array}$ \\
\hline \multicolumn{3}{|l|}{ M2 (Reel) } \\
\hline $\begin{array}{l}\text { Hodrick-Prescott } \\
(\lambda=15)\end{array}$ & $\begin{array}{l}-0.05 \\
(0.12)\end{array}$ & $\begin{array}{c}0.09 \\
(0.09)\end{array}$ \\
\hline $\begin{array}{l}\text { Hodrick-Prescott } \\
(\lambda=1600)\end{array}$ & $\begin{array}{c}0.23 \\
(0.13) \\
\end{array}$ & $\begin{array}{c}0.28 \\
(0.14)\end{array}$ \\
\hline Baxter-King & $\begin{array}{c}0.26 \\
(0.14) \\
\end{array}$ & $\begin{array}{c}0.36 \\
(0.17)\end{array}$ \\
\hline Logaritmik Birinci Fark & $\begin{array}{l}-0.02 \\
(0.16)\end{array}$ & $\begin{array}{c}0.17 \\
(0.10)\end{array}$ \\
\hline \multicolumn{3}{|l|}{ M3 (Reel) } \\
\hline $\begin{array}{l}\text { Hodrick-Prescott } \\
(\lambda=15)\end{array}$ & $\begin{array}{l}-0.001 \\
(0.11) \\
\end{array}$ & $\begin{array}{c}0.12 \\
(0.08)\end{array}$ \\
\hline $\begin{array}{l}\text { Hodrick-Prescott } \\
(\lambda=1600)\end{array}$ & $\begin{array}{c}0.29 \\
(0.11) \\
\end{array}$ & $\begin{array}{c}0.32 \\
(0.13)\end{array}$ \\
\hline Baxter-King & $\begin{array}{c}0.31 \\
(0.13) \\
\end{array}$ & $\begin{array}{c}0.39 \\
(0.16)\end{array}$ \\
\hline Logaritmik Birinci Fark & $\begin{array}{c}0.04 \\
(0.14)\end{array}$ & $\begin{array}{c}0.21 \\
(0.10)\end{array}$ \\
\hline \multicolumn{3}{|c|}{ Para Dolaşım Miktarı (M3) } \\
\hline $\begin{array}{l}\text { Hodrick-Prescott } \\
(\lambda=15)\end{array}$ & $\begin{array}{c}0.42 \\
(0.09) \\
\end{array}$ & $\begin{array}{c}0.22 \\
(0.10) \\
\end{array}$ \\
\hline $\begin{array}{l}\text { Hodrick-Prescott } \\
(\lambda=1600)\end{array}$ & $\begin{array}{c}0.10 \\
(0.14) \\
\end{array}$ & $\begin{array}{l}-0.04 \\
(0.17) \\
\end{array}$ \\
\hline Baxter-King & $\begin{array}{c}0.03 \\
(0.17) \\
\end{array}$ & $\begin{array}{l}-0.17 \\
(0.20)\end{array}$ \\
\hline Logaritmik Birinci Fark & $\begin{array}{c}0.41 \\
(0.12) \\
\end{array}$ & $\begin{array}{c}0.14 \\
(0.15)\end{array}$ \\
\hline
\end{tabular}

Not: Serilere filtreleme yöntemleri uygulanmadan önce seriler mevsimsellikten arındırılmıştır. Mevsimsellikten arındırılan serilerin logaritması alınmış ve daha sonra farklı filtreleme yöntemleriyle serilerin çevrimsel bileşenleri elde edilmiştir. Logaritmik birinci fark yöntemi için filtreleme yöntemi uygulanmayan seriler kullanılmıştır. GMM 
yöntemiyle elde edilen standart hatalar parantez içerisinde belirtilmiştir.

Tablo 7 - Devam

\begin{tabular}{|c|c|c|}
\hline & $\begin{array}{c}\text { 1987.Q1-2016.Q3 IFS } \\
\text { Verileri }\end{array}$ & $\begin{array}{c}\text { 1998.Q1-2016.Q3 } \\
\text { Zincirlenmiş Veriler }\end{array}$ \\
\hline \multicolumn{3}{|l|}{ Reel Faiz } \\
\hline $\begin{array}{l}\text { Hodrick-Prescott } \\
(\lambda=15)\end{array}$ & $\begin{array}{l}-0.28 \\
(0.08)\end{array}$ & $\begin{array}{l}-0.18 \\
(0.14)\end{array}$ \\
\hline $\begin{array}{l}\text { Hodrick-Prescott } \\
(\lambda=1600)\end{array}$ & $\begin{array}{l}-0.18 \\
(0.07)\end{array}$ & $\begin{array}{l}-0.23 \\
(0.12)\end{array}$ \\
\hline Baxter-King & $\begin{array}{l}-0.13 \\
(0.09)\end{array}$ & $\begin{array}{l}-0.36 \\
(0.16)\end{array}$ \\
\hline Logaritmik Birinci Fark & $\begin{array}{l}-0.26 \\
(0.09) \\
\end{array}$ & $\begin{array}{l}-0.23 \\
(0.10) \\
\end{array}$ \\
\hline \multicolumn{3}{|c|}{ Nominal Efektif Döviz Kuru* } \\
\hline $\begin{array}{l}\text { Hodrick-Prescott } \\
(\lambda=15)\end{array}$ & $\begin{array}{c}0.52 \\
(0.14) \\
\end{array}$ & $\begin{array}{l}-0.02 \\
(0.08)\end{array}$ \\
\hline $\begin{array}{l}\text { Hodrick-Prescott } \\
(\lambda=1600)\end{array}$ & $\begin{array}{l}0.52^{*} \\
(0.11)\end{array}$ & $\begin{array}{l}-0.26 \\
(0.15) \\
\end{array}$ \\
\hline Baxter-King & $\begin{array}{c}0.48 \\
(0.17) \\
\end{array}$ & $\begin{array}{l}-0.31 \\
(0.18)\end{array}$ \\
\hline Logaritmik Birinci Fark & $\begin{array}{c}0.65 \\
(0.09)\end{array}$ & $\begin{array}{c}0.10 \\
(0.15)\end{array}$ \\
\hline \multicolumn{3}{|l|}{ Reel Efektif Döviz Kuru* } \\
\hline $\begin{array}{l}\text { Hodrick-Prescott } \\
(\lambda=15)\end{array}$ & $\begin{array}{c}0.46 \\
(0.14)\end{array}$ & $\begin{array}{l}-0.07 \\
(0.08)\end{array}$ \\
\hline $\begin{array}{l}\text { Hodrick-Prescott } \\
(\lambda=1600)\end{array}$ & $\begin{array}{c}0.41^{*} \\
(0.13)\end{array}$ & $\begin{array}{l}-0.18 \\
(0.11)\end{array}$ \\
\hline Baxter-King & $\begin{array}{c}0.41 \\
(0.17) \\
\end{array}$ & $\begin{array}{l}-0.11 \\
(0.18)\end{array}$ \\
\hline Logaritmik Birinci Fark & $\begin{array}{c}0.75 \\
(0.06)\end{array}$ & $\begin{array}{c}0.01 \\
(0.12)\end{array}$ \\
\hline \multicolumn{3}{|l|}{ Özel Sektör Kredi } \\
\hline $\begin{array}{l}\text { Hodrick-Prescott } \\
(\lambda=15)\end{array}$ & $\begin{array}{c}0.36 \\
(0.15) \\
\end{array}$ & $\begin{array}{c}0.34 \\
(0.16) \\
\end{array}$ \\
\hline $\begin{array}{l}\text { Hodrick-Prescott } \\
(\lambda=1600)\end{array}$ & $\begin{array}{c}0.66 \\
(0.05) \\
\end{array}$ & $\begin{array}{c}0.62 \\
(0.08) \\
\end{array}$ \\
\hline Baxter-King & $\begin{array}{c}0.69 \\
(0.07) \\
\end{array}$ & $\begin{array}{c}0.59 \\
(0.10) \\
\end{array}$ \\
\hline Logaritmik Birinci Fark & $\begin{array}{c}0.30 \\
(0.19)\end{array}$ & $\begin{array}{c}0.42 \\
(0.13)\end{array}$ \\
\hline
\end{tabular}

Not:Serilere filtreleme yöntemleri uygulanmadan önce seriler mevsimsellikten 
arındırılmıștır. Mevsimsellikten arındırılan serilerin logaritması alınmış ve daha sonra farklı filtreleme yöntemleriyle serilerin çevrimsel bileşenleri elde edilmiştir. Logaritmik birinci fark yöntemi için filtreleme yöntemi uygulanmayan seriler kullanılmıştır. GMM yöntemiyle elde edilen standart hatalar parantez içerisinde belirtilmiştir.

${ }^{*}$ Nominal ve reel efektif döviz kuru, veri kısıtı nedeniyle, 1994.Ç1-2016.Ç3 zaman diliminde incelenmiştir.

Tablo 8. Türkiye’nin Makroekonomik Verilerinin Yapışkanlık Değerleri

\begin{tabular}{|c|c|c|c|c|c|c|c|c|c|c|c|c|}
\hline & \multicolumn{4}{|c|}{ 1987.Q1-2016.Q3 IFS Verileri } & \multicolumn{4}{|c|}{ 1998.Q1-2016.Q3 TCMB Verileri } & \multicolumn{4}{|c|}{ 1998.Q1-2016.Q3 Zincirlenmis Verileri } \\
\hline & Lag 1 & Lag 2 & Lag 3 & Lag 4 & Lag 1 & Lag 2 & Lag 3 & Lag 4 & Lag 1 & Lag 2 & Lag 3 & Lag 4 \\
\hline \multicolumn{13}{|l|}{ GSYIH } \\
\hline $\begin{array}{l}\text { Hodrick-Prescott }(\square= \\
1600)\end{array}$ & 0.66 & 0.48 & 0.26 & 0.05 & 0.77 & 0.57 & 0.33 & 0.14 & 0.77 & 0.58 & 0.33 & 0.13 \\
\hline Baxter-King & 0.89 & 0.62 & 0.30 & 0.05 & 0.91 & 0.70 & 0.46 & 0.27 & 0.91 & 0.70 & 0.46 & 0.27 \\
\hline \multicolumn{13}{|l|}{ Tüketim } \\
\hline Hodrick-Prescott $(\square=15)$ & 0.21 & -0.10 & -0.28 & -0.31 & 0.29 & 0.06 & -0.38 & -0.47 & 0.11 & 0.12 & -0.17 & -0.36 \\
\hline $\begin{array}{l}\text { Hodrick-Prescott ( } \square= \\
1600 \text { ) }\end{array}$ & 0.63 & 0.37 & 0.11 & -0.08 & 0.75 & 0.56 & 0.27 & 0.07 & 0.75 & 0.61 & 0.37 & 0.14 \\
\hline Baxter-King & 0.86 & 0.52 & 0.15 & -0.12 & 0.90 & 0.67 & 0.40 & 0.18 & 0.91 & 0.70 & 0.43 & 0.20 \\
\hline $\begin{array}{l}\text { Hodrick-Prescott }(\square= \\
1600)\end{array}$ & 0.78 & 0.56 & 0.28 & 0.06 & 0.81 & 0.59 & 0.31 & 0.09 & 0.84 & 0.60 & 0.31 & 0.08 \\
\hline Baxter-King & 0.89 & 0.61 & 0.28 & -0.004 & 0.92 & 0.71 & 0.47 & 0.27 & 0.91 & 0.71 & 0.47 & 0.28 \\
\hline Logaritmik Birinci Fark & 0.10 & 0.19 & -0.03 & -0.24 & 0.26 & 0.30 & -0.06 & -0.24 & 0.40 & 0.26 & -0.07 & -0.30 \\
\hline \multicolumn{13}{|l|}{ İhracat } \\
\hline Hodrick-Prescott $(\square=15)$ & 0.27 & -0.20 & -0.38 & -0.28 & 0.22 & -0.29 & -0.42 & -0.24 & 0.07 & -0.25 & -0.24 & -0.15 \\
\hline $\begin{array}{l}\text { Hodrick-Prescott }(\square= \\
1600 \text { ) }\end{array}$ & 0.70 & 0.41 & 0.20 & 0.06 & 0.60 & 0.24 & 0.02 & -0.09 & 0.57 & 0.27 & 0.12 & -0.02 \\
\hline Baxter-King & 0.89 & 0.63 & 0.32 & 0.06 & 0.86 & 0.53 & 0.18 & -0.06 & 0.91 & 0.71 & 0.45 & 0.21 \\
\hline \multicolumn{13}{|l|}{ İthalat } \\
\hline Logaritmik Birinci Fark & 0.09 & -0.06 & 0.12 & -0.15 & 0.14 & -0.001 & -0.10 & -0.15 & 0.18 & 0.11 & -0.08 & -0.22 \\
\hline \multicolumn{13}{|l|}{ Net İhracat/GSYİH } \\
\hline Hodrick-Prescott $(\square=15)$ & 0.35 & -0.08 & -0.21 & -0.37 & 0.38 & -0.13 & -0.24 & -0.31 & 0.35 & -0.13 & -0.27 & -0.28 \\
\hline $\begin{array}{l}\text { Hodrick-Prescott ( } \square= \\
1600 \text { ) }\end{array}$ & 0.70 & 0.38 & 0.12 & -0.18 & 0.73 & 0.39 & 0.14 & -0.10 & 0.73 & 0.40 & 0.15 & -0.08 \\
\hline Baxter-King & 0.88 & 0.55 & 0.14 & -0.21 & 0.90 & 0.63 & 0.32 & 0.05 & 0.90 & 0.63 & 0.32 & 0.05 \\
\hline Logaritmik Birinci Fark & 0.07 & -0.07 & 0.04 & -0.19 & 0.15 & -0.12 & 0.000 & -0.13 & 0.14 & -0.09 & -0.04 & -0.14 \\
\hline \multicolumn{13}{|l|}{ Hükümet Harcamalanı } \\
\hline Hodrick-Prescott ( $\square=15$ ) & -0.03 & -0.06 & -0.12 & -0.30 & -0.22 & -0.14 & -0.11 & -0.05 & -0.20 & -0.19 & -0.11 & -0.01 \\
\hline $\begin{array}{l}\text { Hodrick-Prescott }(\square= \\
1600)\end{array}$ & 0.46 & 0.32 & 0.14 & -0.10 & 0.27 & 0.19 & 0.05 & -0.08 & 0.12 & 0.04 & 0.004 & -0.01 \\
\hline Baxter-King & 0.89 & 0.62 & 0.31 & 0.05 & 0.90 & 0.64 & 0.32 & 0.03 & 0.85 & 0.51 & 0.12 & -0.17 \\
\hline Logaritmik Birinci Fark & -0.31 & 0.07 & 0.08 & -0.22 & -0.43 & 0.05 & 0.000 & -0.06 & -0.43 & -0.04 & -0.003 & -0.001 \\
\hline Logaritmik Birinci Fark & -0.21 & -0.01 & -0.06 & 0.11 & 0.41 & 0.13 & -0.10 & -0.29 & 0.41 & 0.13 & -0.10 & -0.29 \\
\hline
\end{tabular}


Tablo 8 - Devam

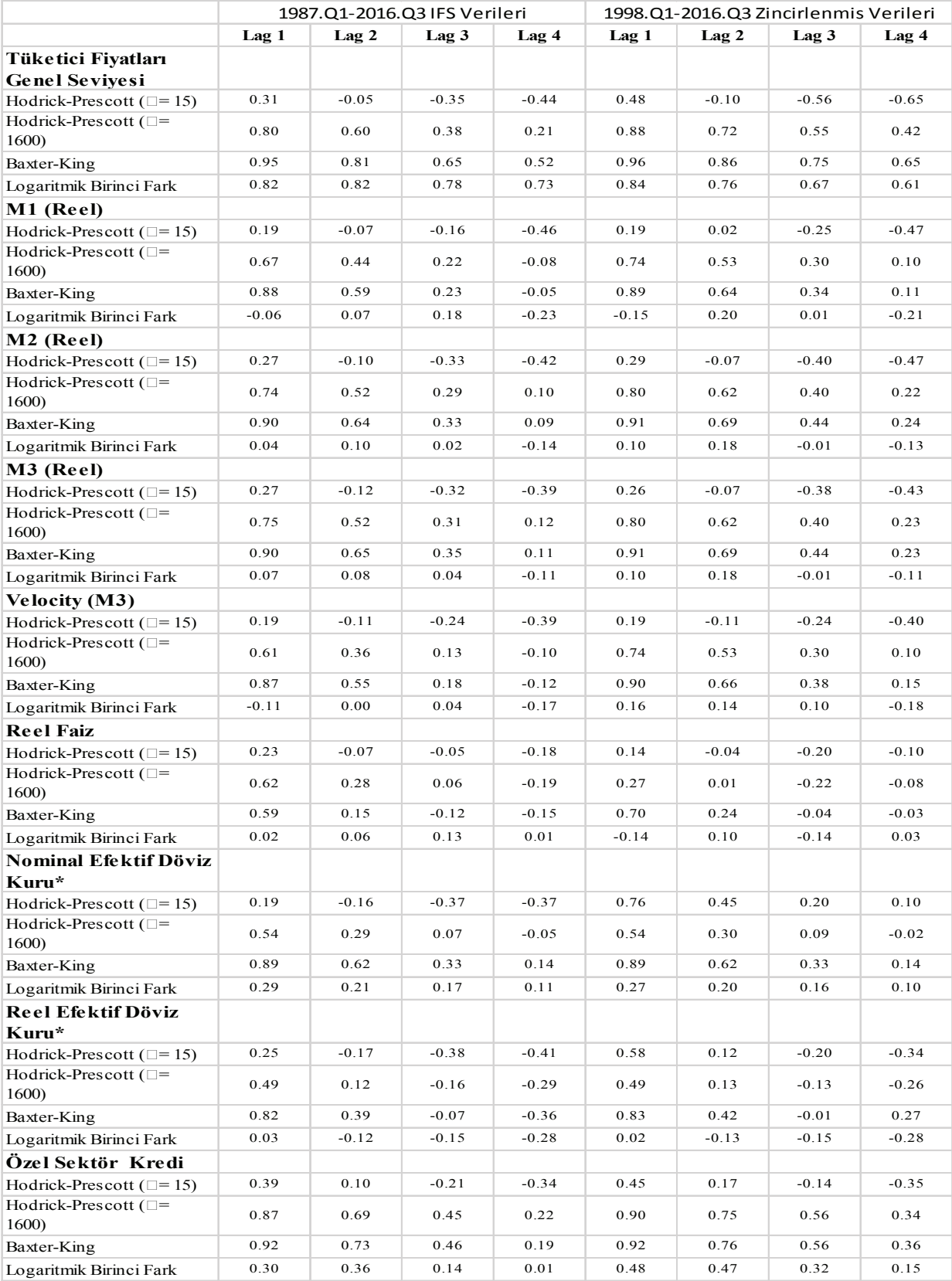

Not: Serilere filtreleme yöntemleri uygulanmadan önce seriler mevsimsellikten 
arındırılmıştır. Mevsimsellikten arındırılan serilerin logaritması alınmış ve daha sonra farklı filtreleme yöntemleriyle serilerin çevrimsel bileşenleri elde edilmiştir. Logaritmik birinci fark yöntemi için filtreleme yöntemi uygulanmayan seriler kullanılmıştır. GMM yöntemiyle elde edilen standart hatalar parantez içerisinde belirtilmiştir.

${ }^{*}$ Nominal ve reel efektif döviz kuru, veri kısıtı nedeniyle, 1994.Ç1-2016.Ç3 zaman diliminde incelenmiştir. 